\title{
Famennian (Upper Devonian) conodont zonation: revised global standard
}

\author{
Claudia Spalletta, Maria CRistina Perri, D. JefFrey OVer \& CARlo CorRadini
}

\begin{abstract}
The revision of the Famennian part of the "Late Devonian Standard Conodont Zonation" is based on the in-equivalence between biozones and time, and the rejection of the presumed single phyletic concept on which the previous zonation was based. It is also intended to simplify the zonation, eliminating the zonal groups named after only one taxon, and biozones that are defined by a Last Appearance Datum (LAD). The proposed revision is largely based on the zonation proposed by Ziegler and Sandberg (1990) and is for the most part correlatable using the same zonal markers. Modifications have only been made when strictly necessary, as the aim of the proposal is to maintain the stability of over 50 years of studies. The 22 zones constituting the revised zonation are defined by the First Appearance Datum (FAD) of species or subspecies that have a well-established stratigraphic range and wide geographic distribution. Each zone is named after the taxon for which the FAD defines the lower boundary. For each zone an association of other species useful for its identification is listed. Key words: conodonts, Upper Devonian, Famennian, biostratigraphy, biozonation.
\end{abstract}

Spalletta, C., Perri, M.C., Over, D.J. \& Corradini, C. 2017. Famennian (Upper Devonian) conodont zonation: revised global standard. Bulletin of Geosciences 92(1), 31-57 (9 figures, 1 table). Czech Geological Survey, Prague. ISSN 1214-1119. Manuscript received July 27, 2016; accepted in revised form February 9, 2017; published online March 27, 2017; issued March 31, 2017.

Claudia Spalletta, Dipartimento di Scienze Biologiche, Geologiche e Ambientali, Alma Mater Studiorum-Università di Bologna, via Zamboni 67, I-40126 Bologna, Italy; claudia.spalletta@ unibo.it• Maria Cristina Perri, Dipartimento di Scienze Biologiche, Geologiche e Ambientali, Alma Mater Studiorum-Università di Bologna, via Zamboni 67, I-40126 Bologna, Italy; mariacristina.perri@ unibo.it • D. Jeffrey Over, Department of Geological Sciences, State University of New York College at Geneseo, Geneseo, NY 14454, USA; over@geneseo.edu • Carlo Corradini, Dipartimento di Scienze Chimiche e Geologiche, Università di Cagliari, via Trentino 51, I-09129 Cagliari, Italy; corradin@unica.it

The "Late Devonian Standard Conodont Zonation" of Ziegler \& Sandberg (1990), based mainly on the zonation first proposed by Ziegler (1962), utilized a definition of biozones that implies a correspondence with a timespan, against the rules of the International Stratigraphic Guide. This assumes a short time of worldwide diffusion of pelagic species, and the occurrence of species to be near synchronous. It should be clear that a biozone is not a time interval but bodies of strata defined or characterized on the base of their fossil content. A comprehensive discussion on the problem of considering a biozone as equivalent to time is reported in Johnson (1992), for detailed information about terminology see also Owen $(1987,2009)$.

Ziegler \& Sandberg (1990) defined the base of each Upper Devonian conodont zone by "the first occurrence of a diagnostic species that can be or not the zonal name giver", although the base of two zones is defined by the extinction of taxa. The top of each zone was defined by "the first occurrence of another diagnostic species or subspecies which preferably is the phyletically next younger taxon" (Ziegler \& Sandberg 1990, p. 12). The correspondence of a biozone with a timespan was "silently" rejected by most conodont workers studying the Upper Devonian, as they continued to use the terms Lower and Upper for the zones, instead of Early and Late as suggested by Ziegler \& Sandberg (1990). Apart from this, the "Late Devonian Standard Conodont Zonation" has been widely used since its publication. In the following text, the original zones of Ziegler \& Sandberg (1990) will be cited as Lower, Middle, Upper and Uppermost instead of using the original denomination Early, Middle, Late and Latest, as in Fig. 1.

The Frasnian part of the "Standard Zonation" is the result of subsequent revisions of the original zonation of Ziegler $(1962,1971)$ by Sandberg et al. $(1988,1989)$ and Ziegler \& Sandberg (1990). The scheme is still widely used, but it could, and should, be easily substituted by the Frasnian zonation initially proposed by Klapper (1989) for the Montagne Noire and then demonstrated to be valid worldwide by Klapper \& Foster (1993), Klapper et al. (1996, 2004), and Klapper (2007a). The zonation of Klapper (1989) is based on taxonomic concepts different from those used by Ziegler \& Sandberg (1990). For the 
identification of species Ziegler and Sandberg, as common practice for Late Devonian faunas, used visual discrimination of P1 (= Pa) elements; Klapper used multielement taxonomy and shape analysis of P1 elements, as well as visual discrimination for zone defining taxa. Zones were delineated by the FAD of species of different genera, several considered by Ziegler \& Sandberg (1990) to inhabit more shallow water environments (e.g. Ancyrodella and Ancyrognathus) than Palmatolepis and Mesotaxis, which predominate in pelagic environments. Klapper (1989, 1997) demonstrated with graphic correlation that first occurrences of species of Ancyrodella, Ancyrognathus, and Ozarkodina are as consistent as those of Palmatolepis species. The Frasnian zonation (FZ) of Klapper (also known as Montagne Noire Zonation) consists of thirteen zones, the last of which (Frasnian Zone 13) was subdivided into three parts by Girard et al. (2005). The FZ is a more detailed subdivision of the Frasnian in respect to the "Standard Zonation", which is composed of nine zones. The graphic correlation scheme for the Frasnian allows an even finer biostratigraphic resolution than 15 zones, but only where faunas are abundant and where sampling is dense. Despite the opinion of some authors (e.g. Ziegler \& Sandberg 1994) that it is impossible to correlate the two zonal schemes, Klapper \& Becker (1999) demonstrated numerous equivalencies and corresponding intervals based on the re-sampling of the Martenberg section - one of the reference sections of Ziegler \& Sandberg (1990). The supposed difficulty of applying the taxonomic concept of Klapper is inconsistent as the Frasnian Zonation can be quite easily applied using the "traditional" identification of conodonts through visual discrimination of only the P1 element.

The Famennian part of the "Standard Zonation" of Ziegler \& Sandberg (1990) includes subsequent additions and slight modifications of the original zonation of Ziegler (1962) by Ziegler (1969), Sandberg \& Ziegler (1973), Sandberg et al. (1978, 1989), and Ziegler \& Sandberg (1984).

Ziegler \& Sandberg (1990) suggested that a zone can be recognized by a distinctive association of conodont elements in the absence of the diagnostic taxon. This suggestion allowed a wide use of the Famennian part of their zonation in the last decades. After the extinction event at the top of the Frasnian, conodonts rapidly recovered and spread worldwide with many representatives of the pelagic genus Palmatolepis.

One of the zonal markers of the "Standard Zonation", Scaphignathus velifer velifer Helms, already used by Ziegler (1962), was not considered a pelagic species, but an inhabitant of shallow water environments. Ziegler \& Sandberg (1984) discussed possible biofacies influences on the formal zonal scheme, but kept Scaphignathus velifer velifer as the marker of the Uppermost marginifera Zone that replaced the velifer Zone of Ziegler (1962). Hartenfels
(2011) and Hartenfels \& Becker (2016) confirmed that it is a typical dweller of pelagic facies in southern Morocco, reaching frequently the deepest part of the basin.

The lower boundary of two other biozones of Ziegler \& Sandberg $(1984,1990)$ was defined by the LAD of representatives of Palmatolepis. The definition of the lower boundary of the Upper rhomboidea Zone corresponds to the extinction of Palmatolepis poolei Sandberg \& Ziegler. The identification of the base of the Upper rhomboidea Zone is difficult where $P a$. poolei - a rare taxon - is not present, as in most sections in the Carnic Alps, Germany, Montagne Noire and Morocco. The definition of the Middle praesulcata Zone by the extinction of Pa. gracilis gonioclymeniae Müller resulted in a great difficulty for the recognition of this zone (Over 1992, Kürschner et al. 1993, Perri \& Spalletta 2000, Kaiser 2005), and some authors suggested alternative proposals (Corradini 2008, Kaiser et al. 2009, Corradini et al. 2016). Ziegler \& Sandberg (1994) underlined the phylogenetic character of their zonation, and this was criticised by some authors (i.e., Corradini 2008, Kononova \& Weyer 2013) because the lower boundaries of seven biozones of their zonation were defined by the FAD of taxa of five different genera (Scaphignathus, Pseudopolygnathus, Bispathodus, Siphonodella, Protognathodus).

The use of Siphonodella praesulcata Sandberg as the marker of the uppermost part of the "Standard Zonation" has also been criticized for problems in identification of the species, especially in relation to the discrimination between Si. praesulcata and Si. sulcata (Huddle) (Kaiser \& Corradini 2008, 2011). Siphonodella praesulcata was chosen as the marker to connect the last part of the Upper Devonian zonation with the Lower Carboniferous zonation based on representatives of the genus Siphonodella. Unequivocal specimens of Si. praesulcata are rare, and the taxon should not be used as a marker until the taxonomic problems are resolved.

The rarity of some of the markers used by Ziegler \& Sandberg (1990) for the upper part of the "Standard Zonation" drove some authors to propose alternative zonal definitions (Corradini 2008, Kaiser et al. 2009, Hartenfels 2011, Corradini et al. 2016). The upper part of the zonation here presented corresponds to that proposed by Corradini et al. (2016). Some comments can be made on the costatus-kockeli Interregnum (CKI) introduced by Kaiser et al. (2009) recently used by Kaiser et al. (2015) and Becker et al. (2016), among others. According to Kaiser et al. (2009) the costatus-kockeli Interregnum comprises the interval from the base of the Hangenberg Black Shales and their equivalents to the FAD of Protognathodus kockeli, and its lower limit corresponds to a sharp and synchronous extinction event. Kaiser et al. (2009) defined correctly the costatus-kockeli Interregnum as an interval zone, but they also recognized that in sections (Tröpl and Grüne Schneid), 
where the carbonatic sedimentation continued, the interval is characterized by an impoverished fauna mainly composed by protognatodids, polygnathids and branmehlids and suggested to name alternatively the interval corresponding to the costatus-kockeli Interregnum meischneri partial zone. The synchrony of the extinction event and of the beginning of the sedimentation of black shales worldwide has to be proven, even if Becker et al. (2016) considered the two events synchronous at geological scale. As with all major global extinction events in the geologic record, the Hangenberg Extinction Event can be easily discriminated globally. Such events have heightened value (specifically as regards correlative value), if they happen to be associated with the first occurrence of a precisely defined morphologic event preferable in a well-characterized lineage and/or with a spectacular 'flood' of a particular species in a biologic lineage immediately after (or even seeming to coincide with) the extinction event. As well as it has been utilized in definition of the base of the biozone following the Frasnian-Famennian (mid-Upper Devonian) and Permian-Triassic global extinctions. Therefore, we use the FAD of Protognathodus kockeli to define the base of the biozone following the Hangenberg Extinction Event that falls within the upper part of the Bispathodus ultimus Zone.

Ziegler (1962) initially defined zonal groups named after one characteristic species and subdivided a group into "Untere", "Mittlere" and "Obere" zone, when necessary. This concept was maintained in the subsequent modification to the zonation (see Ziegler \& Sandberg 1984). Recently this zonal nomenclature gave rise to another problem, as it seems that recent users of the Ziegler \& Sandberg biozonation have abandoned subdivisions that have led to inaccuracies in biostratigraphic analyses (e.g. referring to the interval from the Lower to the Uppermost crepida zones as a "general" crepida Zone).

\section{Remarks on the Famennian boundaries}

\section{Lower Boundary of the Famennian Stage}

The criterion selected for the definition of the Frasnian/Famennian Boundary by the Subcommission on Devonian Stratigraphy (SDS) in 1989 was that the GSSP had to be sought in relation to the base of the Lower triangularis conodont Zone. The SDS in 1991 decided to have this coincide precisely with the lower boundary of the Lower triangularis Zone. The formal proposal to the International Commission on Stratigraphy (ICS) reported in the SDS Newsletter No. 9 (1993), was: "The recommendation for a GSSP fall at the level though to mark the acme of extinction which is at the base of the Lower triangularis Zone". The recommended GSSP was proposed to be drawn at the base of Bed 32a in the Upper Coumiac Quarry in Montagne Noire (southern France). The selected GSSP was ratified by the ICS and the IUGS in 1993. The only criterion used by Ziegler (1962) and Ziegler \& Sandberg (1990) for defining the base of the Lower triangularis Zone was the FAD of Palmatolepis triangularis. Klapper et al. (1994) suggested using the flood occurrence of Palmatolepis triangularis to "the virtual exclusion of other species of the genus, stratigraphically above the fauna dominated by the characteristic upper Frasnian species" so as to exclude "the extremely rare occurrences of Palmatolepis triangularis a few centimetres lower, within the uppermost (Frasnian) conodont zone". At the time of the ratification of the GSSP for the lower limit of the Famennian stage there were taxonomic problems regarding Palmatolepis triangularis. Ziegler \& Sandberg (1996) questioned the presence of Palmatolepis triangularis in Bed $31 \mathrm{~g}$ reported, but not figured, by Klapper et al. (1994). Ziegler \& Sandberg (1996) not only criticized the taxonomic approach of Klapper, but they also repeated earlier claims (Sandberg et al. 1987, unpublished letter to SDS members) that at Coumiac there is a "mineralized (limonitized) contact representing an angular unconformity" at the top of the Frasnian, and therefore in their opinion the basal part of the Famennian is not represented. No detailed sedimentary or lithological data have been presented to support this last assertion; it was only based on the study of conodont biofacies and association (see Ziegler \& Sandberg, 1996, pp. 161-163). The angular unconformity claim has been rejected by House et al. (2000), based on microfacies studies, which showed several microstromatolithic hardgrounds in the condensed succession that represent minor sedimentary breaks. Klapper (2007b) emphasized that a similar sedimentary break occurs also at Steinbruch Schmidt, the original GSSP contender, and possibly at all marine F/F boundary sections.

Based on the original definition of Klapper et al. (1994), the reintroduction of Pa. ultima as a discrete species, and the restriction of the concept of $P$ a.triangularis to the original diagnosis of the holotype, entering in this acceptation slightly higher in the Lower triangularis Zone, Klapper et al. (2004) proposed a redefinition of the Lower triangularis Zone as characterized by the flood occurrence of Palmatolepis ultima Ziegler immediately above the end Frasnian extinction event. Klapper (2007b) advocated the same definition highlighting the validity of the acme of Palmatolepis ultima as supported by graphic correlation. He also wrote (p. 68): "Additionally, the lowest occurrence of P. subperlobata Branson \& Mehl, 1934 characterizes the lower boundary of the Lower triangularis Zone". He did not propose Palmatolepis subperlobata Branson \& Mehl as a marker because in his opinion the species is too rare to be used as the defining criterion (for the GSSP). Furthermore, he did not want to suggest a possible change of the GSSP criterion. A revised definition of the criterion 
used for the formalization of the lower boundary of the Famennian stage (Frasnian/Famnennian Boundary) is highly desirable, following the proposal by Klapper (2007b), and as shown in the revised GSSP section stratigraphic column by Becker et al. (2012, fig. 22.8).

The use of fossils as criterion for the definition of GSSPs should require maximum accuracy in avoiding taxonomic problems. Problems arising using biostratigraphy for chronostratigraphic correlations are discussed in Klapper (1991) and Murphy (1994).

\section{Upper boundary of the Famennian Stage}

The top of the Famennian corresponds to the lower boundary of the Tournaisian Stage, i.e., the Devonian-Carboniferous Boundary (DCB). Problems concerning both the criterion (entry of the conodont Siphonodella sulcata Huddle) chosen for the definition of the boundary, and the lithology of the section where the GSSP was established (La Serre trench E', Montagne Noire, France) in 1990 (Paproth et al. 1991) have been discussed in several papers (e.g. Ziegler \& Sandberg 1996; Casier et al. 2002; Kaiser 2005, 2009). A redefinition of the boundary was reputed necessary, to which in 2008 the International Commission on Stratigraphy established a working group deputed to propose a new criterion for defining the boundary and identification of a new GSSP. Since then many papers concerning the boundary have appeared (e.g. Kaiser et al. 2009, 2015; Kaiser \& Corradini 2011; Corradini et al. 2011, 2013, 2016; Becker et al. 2013, 2016; Kumpan et al. 2014; Malec 2014; Kalvoda et al. 2015; Matyja et al. 2015; Mossoni et al. 2015). As evidenced in some of the cited papers, siphonodellids with curved shape resembling Si. sulcata, are already present in faunas found below the Hangenberg Black Shales or its equivalents, i.e., in the higher part of the Devonian. A meticulous taxonomic revision of the early forms of siphonodellids is essential and highly desirable, as curved elements like those cited have variably been identified in different papers as Siphonodella praseulcata or Siphonodella sulcata on the base of their stratigraphic position and associated fauna. Probably these elements belong to different, not yet named species (see e.g. Tragelehn 2010). The zonation presented herein includes the Protognathodus kockeli Zone, as proposed by Corradini et al. (2016) which comprises the final part of the Famennian and the first part of the Tournaisian according to the current definition of the boundary (see discussion in Becker et al. 2016, Corradini et al. 2016). This zone corresponds to the kockeli and the sulcata/kuehni zones of Kaiser et al. (2009). Recently, during the International Workshop of the joined Subcommissions on Devonian and Carboniferous Stratigraphy (SDS/SCCS) task group held in Montpellier (France) in September 2016, the "base of kockeli Zone, be- ginning of radiation, top of major regression (top of HSS) and end of mass extinction" was voted as potential boundary horizon and criterion for the redefinition of the base of the Carboniferous. The proposal will be submitted to the ICS for approval.

\section{Zonation}

The zonation (Fig. 1) is largely based on the original zonation by Ziegler (1962) and on the "Late Devonian Standard Conodont Zonation" of Ziegler \& Sandberg (1990). It partly continues and updates revisions by Kaiser et al. (2009) and Hartenfels (2011) respectively for the uppermost and the upper part of the Famennian. A partly coincident new scheme of "standard zones" was introduced without explanations by Becker et al. (eds, 2013). Modifications have only been made when strictly necessary. The proposal is intended to simplify the zonation, naming each zone after the taxon for which FAD defines the lower boundary, and to maintain stability of about 50 years of studies. The proposed new zonation is, for the most part, correlatable to the older zonation schemes as most of the same zonal markers are used. The main difference is that each of the 22 zones is defined by the FAD of a species, or subspecies, that have a well-established stratigraphic range, and a wide geographic distribution. For each zone an association of additional species useful for identification is listed. In a few cases the proposed marker of a zone is a relatively uncommon species and/or absent in some geographic areas. For the definition of these zones an alternative marker for local biozonation is indicated.

The stratigraphic distribution of the species cited in the text and of many other Famennian species is reported in Table 1 in Appendix and/or in Figs. 2-9. Not all Famennian species and/or subspecies known from the literature have been included in Table 1. It is noteworthy that some genera (e.g. Icriodus and Polygnathus) include endemic species and are also characterised by frequent homeomorphy, probably depending on life style and environmental constraints. Since this paper is a proposed standard (global) zonation, we report only taxa that have a documented wide geographical distribution.

\section{Palmatolepis subperlobata Zone}

\section{Lower boundary: FAD of Palmatolepis subperlobata} Upper boundary: FAD of Palmatolepis triangularis

Remarks. - This zone corresponds to the lowest part of the former Lower triangularis Zone. The base is defined by the FAD of Palmatolepis subperlobata immediately above the highest occurrence of species characteristic of the upper Frasnian (i.e., Palmatolepis bogartensis, Pa. winchelli, 
and last representatives of the genus Ancyrodella). The entry of Palmatolepis subperlobata corresponds to the acme of Palmatolepis ultima, the last representative of Palmatolepis that has a FAD within the uppermost part of the Frasnian (Klapper et al. 2004, Girard et al. 2005, Klapper 2007b). The zone is typically developed in the Famennian GSSP section at Coumiac (Schülke 1995, Klapper 2007b, Becker et al. 2012) but it is recognizable worldwide (Klapper 2007a; Huang \& Gong 2016; Perri \& Spalletta, unpublished data).

The zone is characterized by a low diversity fauna that includes several taxa that survived the upper Frasnian biological crisis, such as Icriodus alternatus alternatus, Ic. alternatus helmsi, Ic. iowaensis iowaensis, Mehlina gradata, Pelekysgnathus planus, Polygnathus angustidiscus, and Po. brevilaminus (Fig. 2).

Conodonts useful for the zonal identification. - Palmatolepis delicatula delicatula enters at or immediately above the lower boundary of the zone. Palmatolepis protorhomboidea occurs within the zone.

\section{Palmatolepis triangularis Zone}

Lower boundary: FAD of Palmatolepis triangularis Upper boundary: FAD of Palmatolepis delicatula platys

Remarks. - This zone corresponds to the upper part of the former Lower triangularis Zone. The base is defined by the FAD of Palmatolepis triangularis sensu Klapper in Klapper et al. (2004). The typical locality is the section at the Upper Coumiac Quarry in Montagne Noire (Klapper 2007b).

Conodonts useful for the zonal identification. - The conodont association characteristic of this zone is quite the same of the Palmatolepis subperlobata Zone. Ancyrognathus cryptus enters within the zone. Polygnathus tenellus becomes extinct within the zone (Fig. 2).

\section{Palmatolepis delicatula platys Zone}

Lower boundary: FAD of Palmatolepis delicatula platys Upper boundary: FAD of Palmatolepis minuta minuta

Remarks. - This zone corresponds exactly to the former Middle triangularis Zone of Ziegler \& Sandberg (1990). The original Middle triangularis Zone of Ziegler (1962) was the interval between the entry of Palmatolepis marginata clarki and that of Pa. tenuipuncata. For the lower boundary of the zone Ziegler (1962) indicated the entry of both Palmatolepis marginata clarki and Pa. marginata marginata. Later part of the elements assigned by Ziegler (1962) to Pa. marginata marginata were re-assigned to $P a$. delicatula delicatula and part to Pa. delicatula platys

\begin{tabular}{|c|c|c|}
\hline $\begin{array}{c}\text { Ziegler } \\
(1962,1969)\end{array}$ & $\begin{array}{c}\text { Ziegler \& } \\
\text { Sandberg } \\
(1990)\end{array}$ & $\begin{array}{l}\text { NEW GLOBAL } \\
\text { ZONATION }\end{array}$ \\
\hline $\begin{array}{l}\text { S. sulcata- } \\
\text { Pr. kockeli }\end{array}$ & sulcata & Protognathodus kockeli \\
\hline \begin{tabular}{|l|} 
Low. Protogn. f. \\
\end{tabular} & Late praesulcata & \\
\hline \multirow{3}{*}{ Middle costatus } & Mid. praesulcata & \multirow{3}{*}{ Bispathodus ultimus } \\
\hline & Early praesulcata & \\
\hline & Late expansa & \\
\hline Lower costatus & \multirow{2}{*}{ Middle expansa } & Bispathodus costatus \\
\hline \multirow{2}{*}{ Upper styriacus } & & Bispathodus ac. aculeatus \\
\hline & Early expansa & Palmatolepis gr. expansa \\
\hline Middle styriacus & Late postera & Palmatolepis gr. manca \\
\hline Lower styriacus & Early postera & Polygnathus styriacus \\
\hline Upper velifer & Late trachytera & Pseudopolygnathus granulosus \\
\hline Middle velifer & Early trachytera & Palmatolepis $r$. trachytera \\
\hline Lower velifer & Latest marginifera & Scaphignathus v. velifer \\
\hline $\begin{array}{c}\text { Upper } \\
\text { quadrantinodosa }\end{array}$ & Late marginifera & Palmatolepis marg. utahensis \\
\hline $\begin{array}{c}\text { Lower } \\
\text { quadrantinodosa }\end{array}$ & Early marginifera & Palmatolepis marg. marginifera \\
\hline \multirow{2}{*}{ rhomboidea } & Late rhomboidea & Palmatolepis gr. gracilis \\
\hline & Early rhomboidea & Palmatolepis rhomboidea \\
\hline \multirow{2}{*}{ Upper crepida } & Latest crepida & Palmatolepis gl. pectinata \\
\hline & Late crepida & Palmatolepis gl. prima \\
\hline Middle crepida & Middle crepida & Palmatolepis termini \\
\hline Lower crepida & Early crepida & Palmatolepis crepida \\
\hline Upper triangularis & Late triangularis & Palmatolepis min. minuta \\
\hline Middle triangularis & Middle triangularis & Palmatolepis del. platys \\
\hline \multirow{2}{*}{ Lower triangularis } & \multirow{2}{*}{ Early triangularis } & Palmatolepis triangularis \\
\hline & & Palmatolepis subperlobata \\
\hline
\end{tabular}

Figure 1. Comparison between the revised global conodont biozonation and the zonation schemes of Ziegler $(1962,1969)$ and Ziegler \& Sandberg (1990). The thickness of zones is calibrated according to their supposed duration, as estimated in the Devonian chapter of The Geologic Time Scale 2012 (Becker et al. 2012).

(Ziegler \& Sandberg 1990). The elements assigned by Ziegler (1962) to Palmatolepis marginata clarki have been 
partly re-assigned to $\mathrm{Pa}$. clarki and part to Pa. protorhomboidea (see Ziegler \& Sandberg 1990 for synonymy list). Palmatolepis clarki sensu Ziegler \& Sandberg (1990) enters slightly higher than Pa. delicatula platys. The only remaining species which has the FAD corresponding with the lower boundary given by Ziegler (1962) for this zone is Pa. delicatula platys. According to Schülke (1995) Pa. delicatula platys is rare outside the Rhenish Massif whereas $\mathrm{Pa}$. clarki is more common and can be used to identify the zone in the absence of the marker.

Conodonts useful for the zonal identification. - Ancyrognathus sinelaminus enters at the base of this zone, Palmatolepis clarki appears slightly above, Icriodus cornutus, and Ic. iowaensis ancylus enter within the zone. Palmatolepis ultima becomes extinct at the top (Fig. 2).

\section{Palmatolepis minuta minuta Zone}

Lower boundary: FAD of Palmatolepis minuta minuta Upper boundary: FAD of Palmatolepis crepida

Remarks. - This zone is equivalent to the former Upper triangularis Zone of Ziegler \& Sandberg (1990). The lower boundary of the original Upper triangularis Zone of Ziegler (1962) corresponded to the entry of Palmatolepis tenuipunctata. Ziegler \& Sandberg (1990) did not explain the change of the taxon defining the lower boundary of the zone. Both Palmatolepis minuta minuta and Pa. tenuipunctata enter at the base of the zone, therefore the definition given by Ziegler \& Sandberg (1990) is maintained. In the Famennian Composite Standard, constructed by graphic correlation, the lowest occurrence of both taxa is in the same sample at the Upper Coumiac Quarry (Klapper, personal communication).

Conodonts useful for the zonal identification. - Palmatolepis perlobata perlobata, Pa. regularis, Pa. sandbergi, $P a$. tenuipunctata, and $P a$. werneri enter at the base of the zone. Palmatolepis lobicornis, Pa. spathula, Polygnathus eoglaber, and Po. procerus, in the sense of the holotype by Sannemann 1955, first appear within the zone. Icriodus deformatus asymmetricus and Ic. deformatus deformatus become extinct (Fig. 2).

\section{Palmatolepis crepida Zone}

Lower boundary: FAD of Palmatolepis crepida Upper boundary: FAD of Palmatolepis termini

Remarks. - The zone corresponds to the former Lower $c r e$ pida Zone.

Conodonts useful for the zonal identification. - Palmatolepis minuta loba, Pa. quadrantinodosalobata M2, and
$P a$. wolskajae have their first appearance at the base of the zone, Polygnathus communis communis and Po. nodocostatus nodocostatus within the zone. Palmatolepis clarki, $P a$. delicatula platys, Pa. sandbergi, and Pa. triangularis become extinct within the zone; Palmatolepis delicatula delicatula near the top, and $\mathrm{Pa}$. spathula at the top (Fig. 2).

\section{Palmatolepis termini Zone}

Lower boundary: FAD of Palmatolepis termini Upper boundary: FAD of Palmatolepis glabra prima-M3 of Hartenfels (2011), typical morphotype

Remarks. - This zone is equivalent to the former Middle crepida Zone.

Conodonts useful for the zonal identification. - Ancyrolepis cruciformis is characteristic of this zone. Palmatolepis minuta wolskae enters at the base of the zone; Mehlina strigosa, Pa. circularis, Po. lauriformis, and Po. semicostatus within the zone. In the Montagne Noire is registered the lowest occurrence of Polygnathus glaber glaber, entering within the biozone (Girard et al. 2014). Polygnathus angustidiscus becomes extinct within the zone, Icriodus alternatus helmsi at the top (Fig. 2).

\section{Palmatolepis glabra prima Zone}

Lower boundary: FAD of Palmatolepis glabra prima-M3 of Hartenfels (2011), typical morphotype

Upper boundary: FAD of Palmatolepis glabra pectinataM2 of Hartenfels (2011), typical morphotype sensu Ziegler \& Sandberg (1984)

Remarks. - The zone is equivalent to the former Upper crepida Zone.

Conodonts useful for the zonal identification. - Palmatolepis adamantea and $\mathrm{Pa}$. minuta subgracilis have their first appearance at the base of the zone. Palmatolepis glabra lepta, Pa. klapperi and Pa. perlobata schindewolfi first appear within the zone. Palmatolepis wolskajae becomes extinct within the zone, Pa. circularis, and Pa.termini at the top (Fig. 3).

\section{Palmatolepis glabra pectinata Zone}

Lower boundary: FAD of Palmatolepis glabra pectinataM2 of Hartenfels (2011), typical morphotype sensu Ziegler \& Sandberg (1984)

Upper boundary: FAD of Palmatolepis rhomboidea

Remarks. - The zone corresponds to the former Uppermost crepida Zone. 


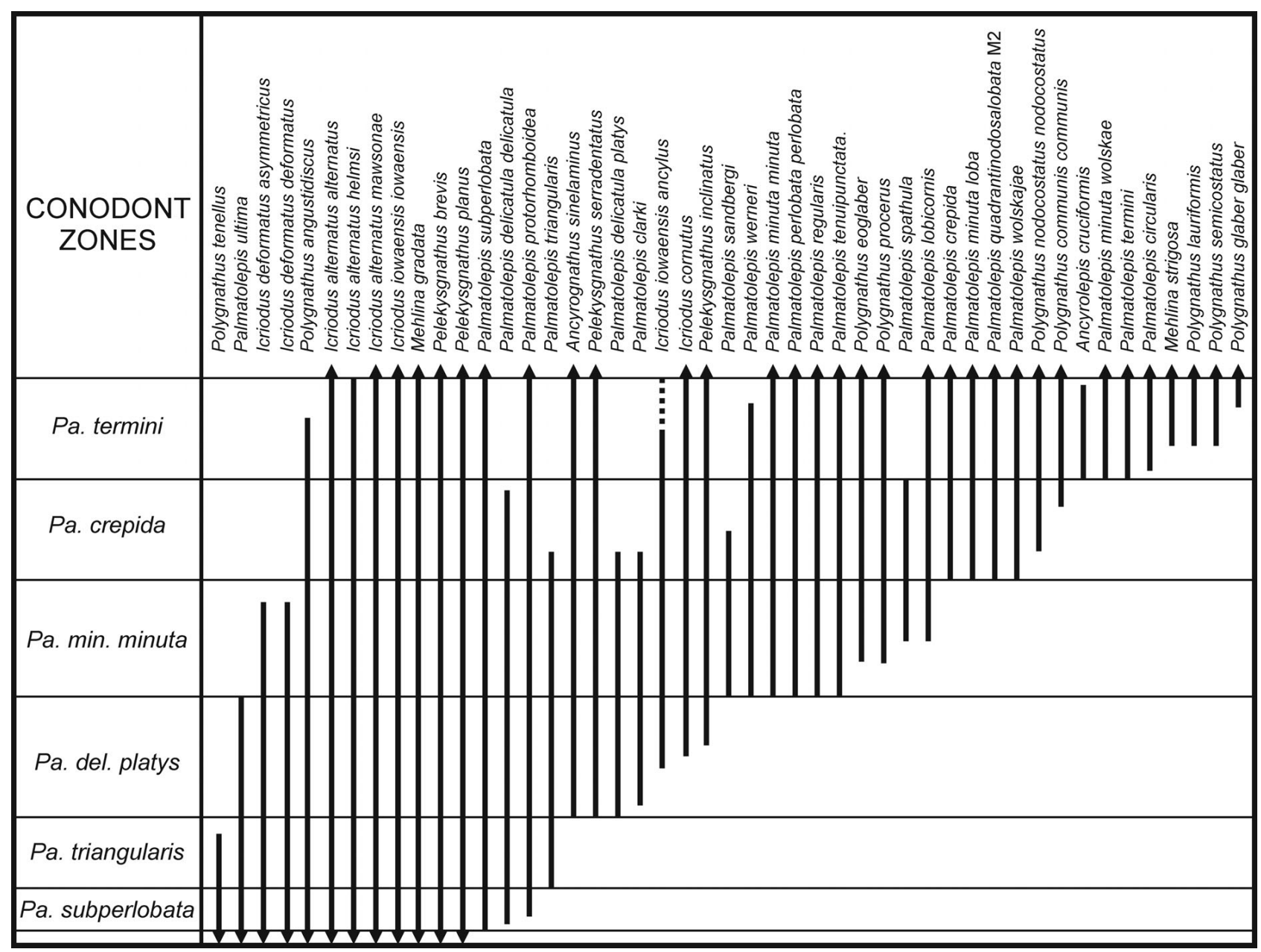

Figure 2. Stratigraphic distribution of the main Famennian conodont species and subspecies from the Palmatolepis subperlobata Zone to the Palmatolepis termini Zone.

Conodonts useful for the zonal identification. - Palmatolepis glabra acuta starts at the lower boundary of the zone. Icriodus olivierii, Polygnathus padovanii, Po. rhomboideus and Polylophodonta linguiformis have their first appearance within the zone. Ancyrognathus cryptus, Anc. sinelaminus, Icriodus alternatus alternatus, Palmatolepis perlobata perlobata, Pa. tenuipunctata, and Polygnathus procerus become extinct within the biozone, $\mathrm{Pa}$. adamantea at the top (Fig. 3).

\section{Palmatolepis rhomboidea Zone}

Lower boundary: FAD of Palmatolepis rhomboidea Upper boundary: FAD of Palmatolepis gracilis gracilis

Remarks. - The zone corresponds to the former Lower rhomboidea Zone and the lowermost part of the Upper rhomboidea Zone sensu Sandberg \& Ziegler (1973).

Conodonts useful for the zonal identification. - Palmatole- pis glabra glabra, Pa. poolei, and Polylophodonta confluens enter at the base of the zone. The range of Palmatolepis poolei is restricted to the zone and it becomes extinct near the top. Polygnathus diversus first appears within the zone. Icriodus chojnicensis, and Palmatolepis minuta schleizia enter near the top of the zone. Icriodus iowaensis iowaensis, Ic. olivierii, Palmatolepis lobicornis, Pa. minuta wolskae, $\mathrm{Pa}$. protorhomboidea, $\mathrm{Pa}$. quadrantinodosalobata, and $P a$. regularis become extinct within the zone. Palmatolepis crepida, Pa. minuta loba, and Pa. minuta subgracilis near the top (Fig. 3).

\section{Palmatolepis gracilis gracilis Zone}

Lower boundary: FAD of Palmatolepis gracilis gracilis Upper boundary: FAD of Palmatolepis marginifera marginifera

Remarks. - This new zone corresponds to most of the former Upper rhomboidea Zone. The base is defined by the 


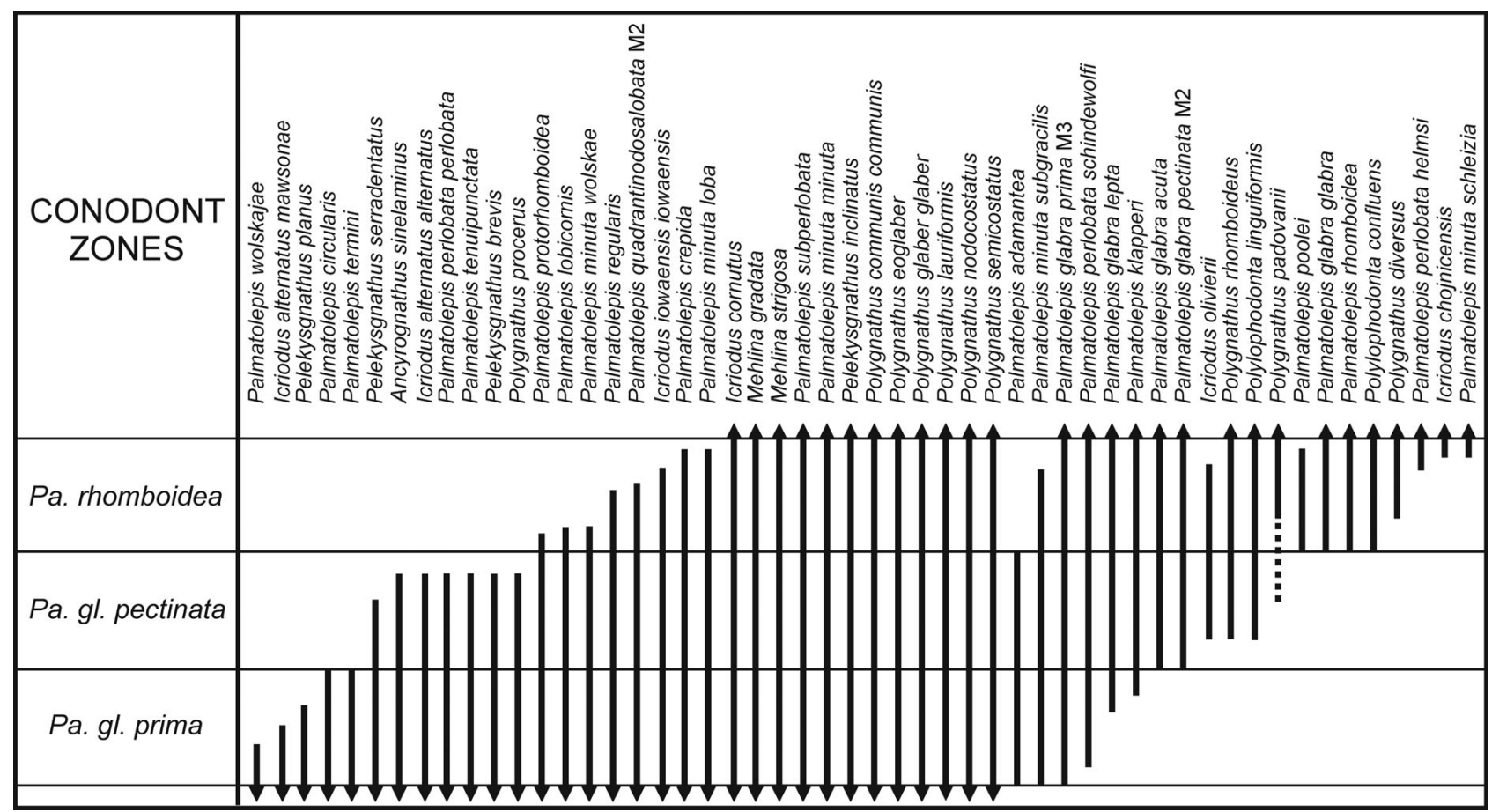

Figure 3. Stratigraphic distribution of the main Famennian conodont species and subspecies from the Palmatolepis glabra prima Zone to the Palmatolepis rhomoboidea Zone.

FAD of Palmatolepis gracilis gracilis, the nominal subspecies, that is easy to recognize and characterized by a worldwide geographic distribution. The FAD of Palmatolepis gracilis gracilis is slightly higher than the LAD of $P a$. poolei, which defined the base of the Upper rhomboidea Zone of Sandberg \& Ziegler (1973) and Ziegler \& Sandberg (1990). The choice of Palmatolepis gracilis gracilis as the zonal marker avoids a zonal boundary defined by the LAD of Pa. poolei. Palmatolepis poolei is rare and it is not present in some geographic areas (e.g. Montagne Noire). A possible alternative marker to define a new zone could have been Palmatolepis minuta schleizia that according to Ji \& Ziegler (1993) enters at the base of the Upper rhomboidea Zone of the "Standard Zonation". Palmatolepis gracilis gracilis was choosen as it is more common and widespread than Palmatolepis minuta schleizia. The best reference section for this zone is the Lali section (China) of Ji \& Ziegler (1993).

Conodonts useful for the zonal identification. - Bispathodus stabilis vulgaris enters at the base of the zone. Alternognathus pseudostrigosus, Branmehla disparilis, and Palmatolepis quadrantinodosa inflexa enter slightly above the base of this zone. Palmatolepis perlobata maxima enters within the zone. Polygnathus triphyllatus, and Polylophodonta gyratilineata start in the upper half of the zone. Palmatolepis stoppeli first appears near the top. Polygnathus eoglaber, and Po. rhomboideus disappear within the zone (Fig. 4).

\section{Palmatolepis marginifera marginifera Zone}

Lower boundary: FAD of Palmatolepis marginifera marginifera

Upper boundary: FAD of Palmatolepis marginifera utahensis

Remarks. - The zone is equivalent to the former Lower marginifera Zone.

Conodonts useful for the zonal identification. - Palmatolepis quadrantinodosa quadrantinodosa is exclusive of this biozone. Branmehla werneri, Palmatolepis glabra distorta, and Polygnathus glaber medius enter at the base of the zone, $P a$. perlobata sigmoidea slightly above. Palmatolepis marginifera duplicata, Polygnathus glaber bilobatus, and Po. pennatuloideus enter within the zone. Polygnathus tryphillatus becomes extinct within the lower part of the zone, Palmatolepis klapperi, Pa. stoppeli, Pa. subperlobata, and Polylophodonta gyratilineata within the zone, Pa. glabra glabra, and Polygnathus brevilaminus at the top (Fig. 4).

\section{Palmatolepis marginifera utahensis Zone}

Lower boundary: FAD of Palmatolepis marginifera utahensis

Upper boundary: FAD of Scaphignathus velifer velifer 


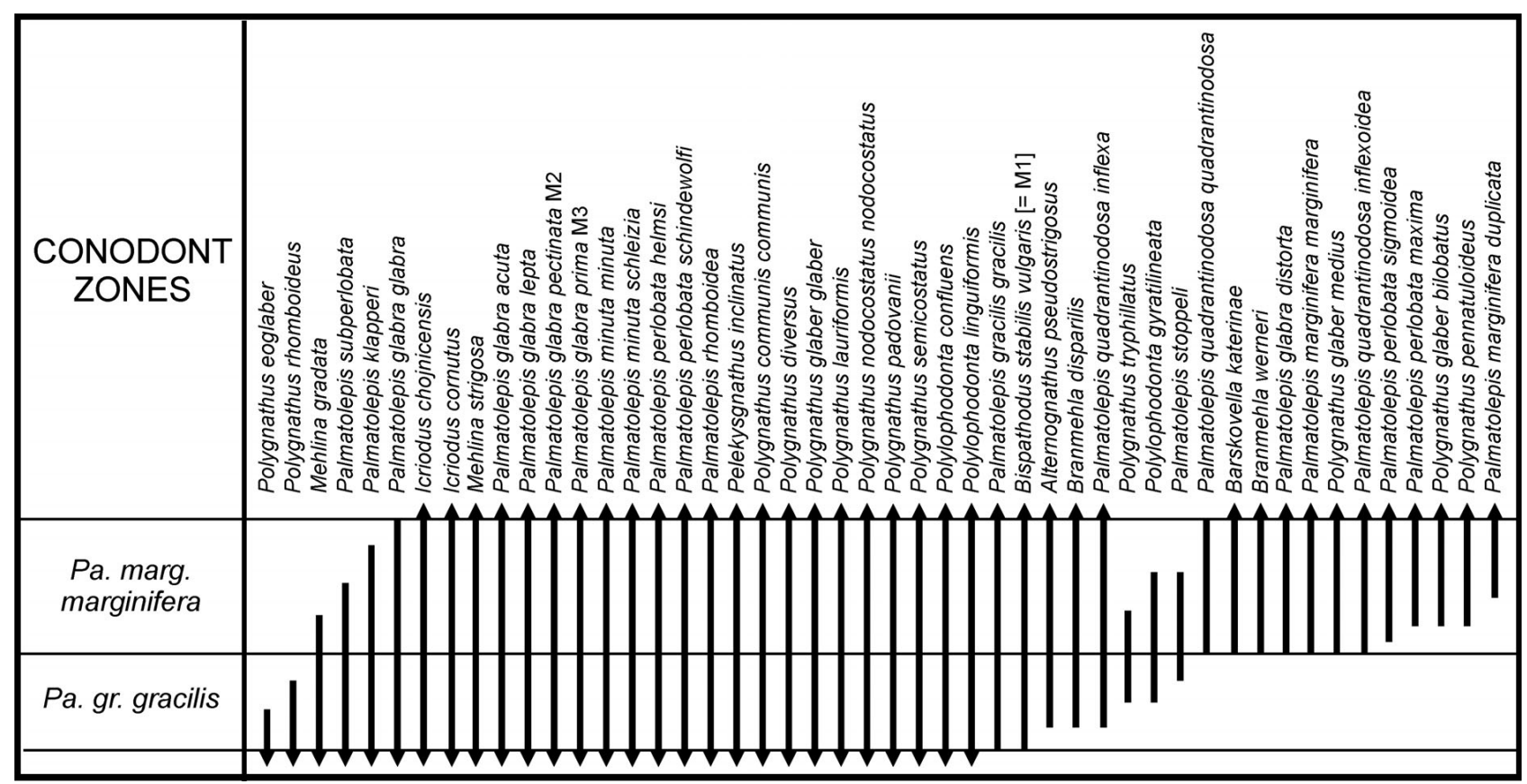

Figure 4. Stratigraphic distribution of the main Famennian conodont species and subspecies from the Palmatolepis gracilis gracilis Zone to the Palmatolepis marginifera marginifera Zone.

Remarks. - This zone is equivalent to the Upper marginifera Zone sensu Ziegler \& Sandberg (1984) and Ziegler \& Sandberg (1990). Sandberg \& Ziegler (1973) defined the zone as "characterized by the range of Palmatolepis marginifera marginifera between the disappearance of $P$ a . quadrantinodosa quadrantinodosa, Pa. quadrantinodosa inflexa, Pa. quadrantinodosa inflexoidea and the first appearance of Scaphignathus velifer". Ziegler \& Sandberg (1984) introduced the new subspecies Palmatolepis marginifera utahensis and defined the lower boundary of the present zone by the first appearance of the new taxon.

Conodonts useful for the zonal identification. - Branmehla inornata and Palmatolepis rugosa cf. ampla first appear at the base of the zone. Polygnathus marginvolutus, and Po. perplexus first appear within the zone. The occurrence of Branmehla bohlenana bohlenana, Palmatolepis perlobata grossi, Polygnathus granulosus, Po. lagowiensis, and Po. nodoundatus allow the identification of the upper part of the zone. Palmatolepis glabra acuta, Pa. glabra pectinata, Pa. marginifera duplicata, Pa. quadrantinodosa inflexa, Pa. quadrantinodosa inflexoidea, Pa. rhomboidea, and Polylophodonta linguiformis go extinct within the zone, Pa. glabra prima, and Polygnathus glaber medius at the top (Fig. 5).

\section{Scaphignathus velifer velifer Zone}

Lower boundary: FAD of Scaphignathus velifer velifer Upper boundary: FAD of Palmatolepis rugosa trachytera
Remarks. - The present zone corresponds to the Uppermost marginifera Zone. Scaphignatus velifer velifer in some geographic areas is a rare taxon; where absent Alternognathus beulensis and/or Alt. regularis can be used for the identification of the lower boundary of this zone, as these taxa enter at the same level as Scaphignatus velifer velifer. We considered to name the zone after one of the two species of Alternognathus but opted for continuity with the original definition. The genus Alternognathus was regarded by Ziegler \& Sandberg (1984) as characteristic of a more offshore environment, and therefore environmentally less restricted than Scaphignathus. The different environment was reputed by the authors as sufficient reason to define a new genus, but in fact elements attributed by Ziegler \& Sandberg (1984) to their new genus were previously considered as representatives of Scaphignathus. The use of Scaphignathus velifer velifer as nominal marker of the same biozone was already suggested at local or supraregional level by Corradini (2008) and Hartenfels (2011).

Conodonts useful for the zonal identification. - Alternognathus beulensis and Alt. regularis have their FAD at the lower boundary of the zone. Icriodus costatus, and Ic. raymondi start near the lower boundary of the zone, and Scaphignathus velifer leptus slightly above. Palmatolepis marginifera utahensis, Polygnathus lauriformis, and Po. lagowiensis become extinct within the biozone, Icriodus chojnicensis, and Polylophodonta confluens at the top (Fig. 5). 


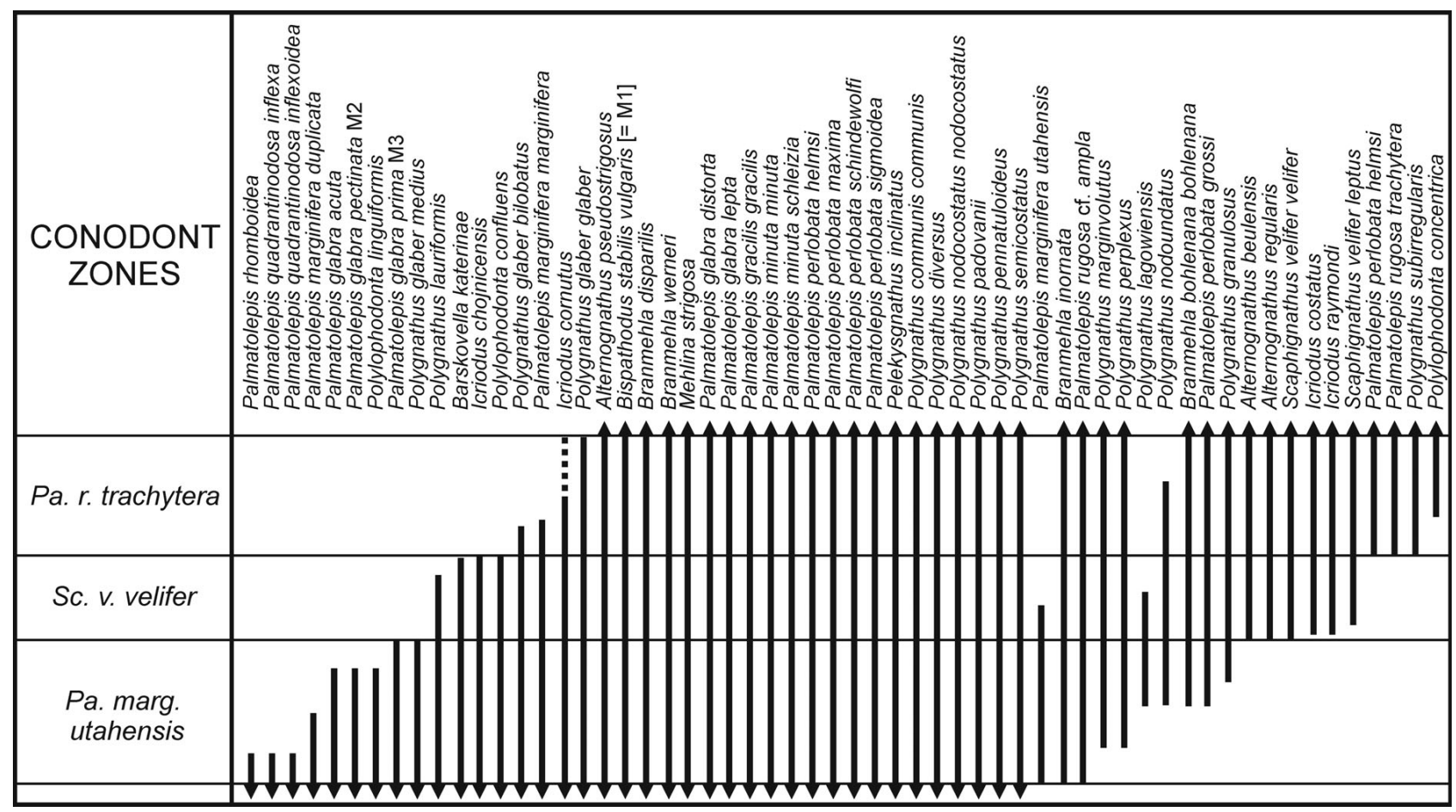

Figure 5. Stratigraphic distribution of the main Famennian conodont species and subspecies from the Palmatolepis marginifera uthaensis Zone to the Scaphignathus velifer velifer Zone.

\section{Palmatolepis rugosa trachytera Zone}

Lower boundary: FAD of Palmatolepis rugosa trachytera Upper boundary: FAD of Pseudopolygnathus granulosus

Remarks. - The zone is equivalent to the former Lower trachytera Zone.

Conodonts useful for the zonal identification. - Palmatolepis perlobata helmsi and Polygnathus subirregularis enter at the lower boundary of the zone. Palmatolepis marginifera marginifera, and Polygnathus glaber bilobatus become extinct in the lower part of the biozone, Po. nodoundatus within it, and Po. glaber glaber at the top (Fig. 5).

\section{Pseudopolygnathus granulosus Zone}

Lower boundary: FAD of Pseudopolygnathus granulosus Upper boundary: FAD of Polygnathus styriacus

Remarks. - The zone is equivalent to the former Upper trachytera Zone. The zone was subdivided by Hartenfels (2011) into three regional subzones recognized also in other geographic areas (Hartenfels \& Becker 2016). The Palmatolepis gracilis sigmoidalis subzone of Hartenfels (2011) can be useful for the recognition of the middle part of the zone. The trachytera-styriacus Interregnum of Hartenfels (2011) is the interval zone between the disappear- ance of Palmatolepis rugosa trachytera and the appearance of Polygnathus styriacus, which corresponds to the interval comprising the lower and upper Annulata extinction events in the uppermost part of the Zone.

Conodonts useful for the zonal identification. - Palmatolepis gracilis sigmoidalis, Polygnathus homoirregularis, Po. protostyriacus, and Pseudopolygnathus micropunctatus first appear within the central part of the zone. Pseudopolygnathus granulosus and Ps. micropunctatus are the first representatives of the genus. Palmatolepis gracilis sigmoidalis enters in the middle part of the zone. Bispathodus stabilis stabilis (Girard et al. 2017; Perri \& Spalletta, unpublished data), Polygnathus margaritatus and Po. obliquicostatus enter in the upper part. Palmatolepis glabra distorta and Pa. glabra lepta, the last representatives of the species, became extinct within the zone, as well as $P a$. $m i$ nuta minuta and Polygnathus padovanii. Palmatolepis perlobata grossi, Pa. rugosa trachytera, and Scaphignathus velifer velifer become extinct at different levels near the top of the zone during the lower and upper Annulata extinction events. Icriodus cornutus become extinct at the top (Fig. 6).

\section{Polygnathus styriacus Zone}

Lower boundary: FAD of Polygnathus styriacus Upper boundary: FAD of Palmatolepis gracilis manca 


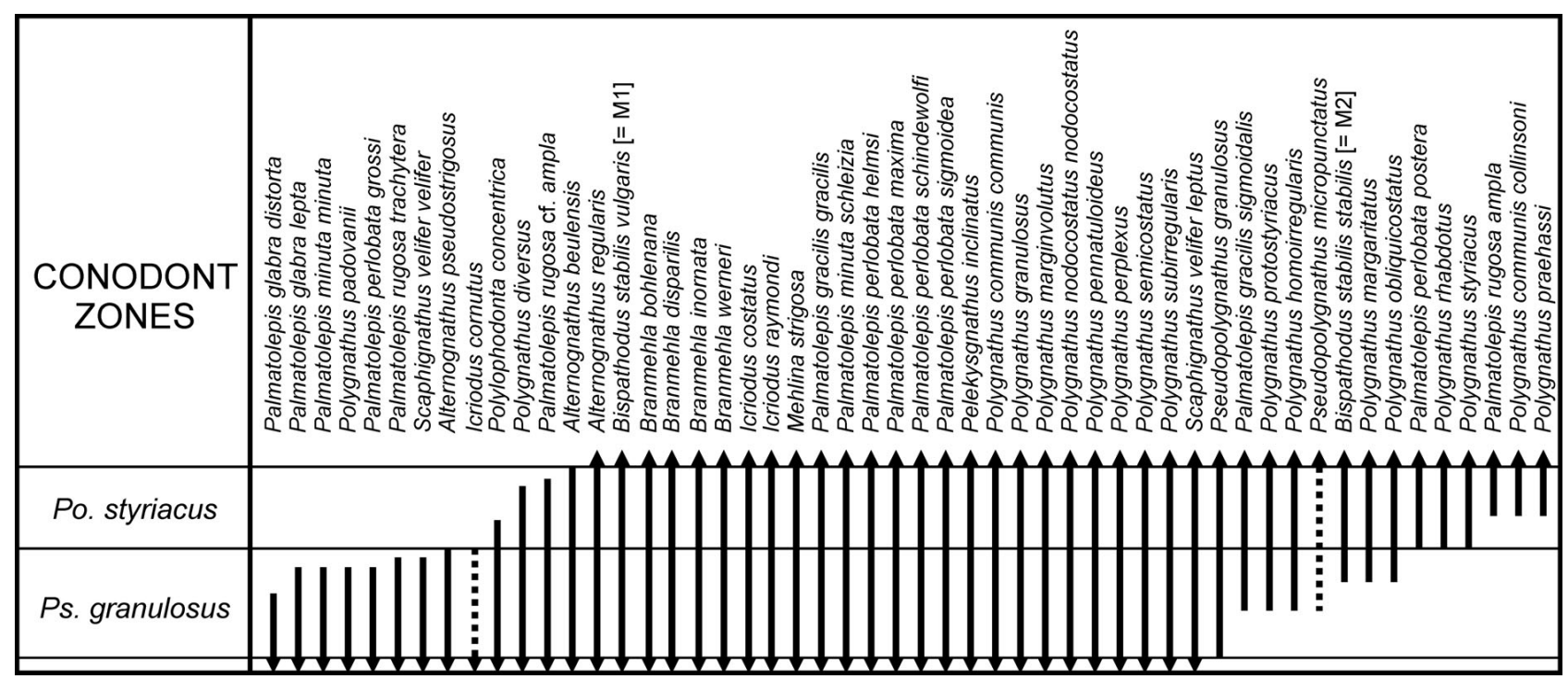

Figure 6. Stratigraphic distribution of the main Famennian conodont species and subspecies from the Pseudopolygnahtus granulosus Zone to the Polygnathus styriacus Zone.

Remarks. - This zone corresponds to the former Lower postera Zone. Palmatolepis perlobata postera is a rare species, and in some localities (i.e., the Carnic Alps) the species enters in higher levels. Polygnathus styriacus is preferred as a zonal marker due to a wider geographic distribution in respect to Palmatolepis perlobata postera, and for historical reasons, as it was chosen as the zonal marker by Ziegler (1962). Ziegler and Sandberg (1984) substituted the Lower styriacus Zone of Ziegler (1962) with the Lower postera Zone in order to name all the zonal groups after species of Palmatolepis. Recently some authors (Corradini 2008, Hartenfels 2011) re-introduced a local or supraregional styriacus Zone for European and North Africa regions, where Palmatolepis perlobata postera is very rare or absent.

Polygnathus styriacus is widely distributed, common in Europe, although rare in the western United States (Sandberg 1979). Where Polygnathus styriacus is rare, the base of the zone can be identified by the entry of Palmatolepis perlobata postera. Typically where Polygnathus styriacus is common Palmatolepis perlobata postera is very rare or absent, and vice versa.

Conodonts useful for the zonal identification. - Palmatolepis perlobata postera and typical Polygnathus rhabdotus enter at the lower boundary of the zone. Palmatolepis rugosa ampla, Polygnathus praehassi, and Polygnathus communis collinsoni enter within the zone. The presence of Polygnathus praehassi can be used to recognize the upper part of the zone. Palmatolepis rugosa cf. ampla, and Polygnathus diversus become extinct near the top of the biozone, Alternognathus beulensis at the top (Fig. 6).

\section{Palmatolepis gracilis manca Zone}

Lower boundary: FAD of Palmatolepis gracilis manca Upper boundary: FAD of Palmatolepis gracilis expansa

Remarks. - This zone corresponds to the former Upper postera Zone. In Sardinia the zonal marker is not present, for this reasons a local, not subdivided, styriacus Zone has been used by Corradini (2008). The zonal index species is extremely rare or absent in North Africa (Hartenfels 2011).

Conodonts useful for the zonal identification. - Bispathodus stabilis bituberculatus (Bi. stabilis M3) and Clydagnathus ormistoni enter at the base of the zone. Bispathodus bispathodus, Pseudopolygnathus controversus, Ps. inordinatus, and Scaphignathus peterseni appear within the zone, Palmatolepis rugosa rugosa and Polygnathus experplexus in the uppermost part. Palmatolepis perlobata sigmoidea, and Pseudopolygnathus granulosus become extinct within the zone, Alternognathus regularis, Palmatolepis minuta schleizia, and Scaphignathus velifer leptus at the top (Fig. 7).

\section{Palmatolepis gracilis expansa Zone}

Lower boundary: FAD of Palmatolepis gracilis expansa Upper boundary: FAD of Bispathdus aculeatus aculeatus

Remarks. - The zone is equivalent to the former Lower expansa Zone. The entry of Bispathodus stabilis stabilis (Bi. stabilis M2) was used by Hartenfels (2011) as the index taxon of a zone considered equivalent to the Lower expansa Zone. The Bispathodus stabilis stabilis Zone of 


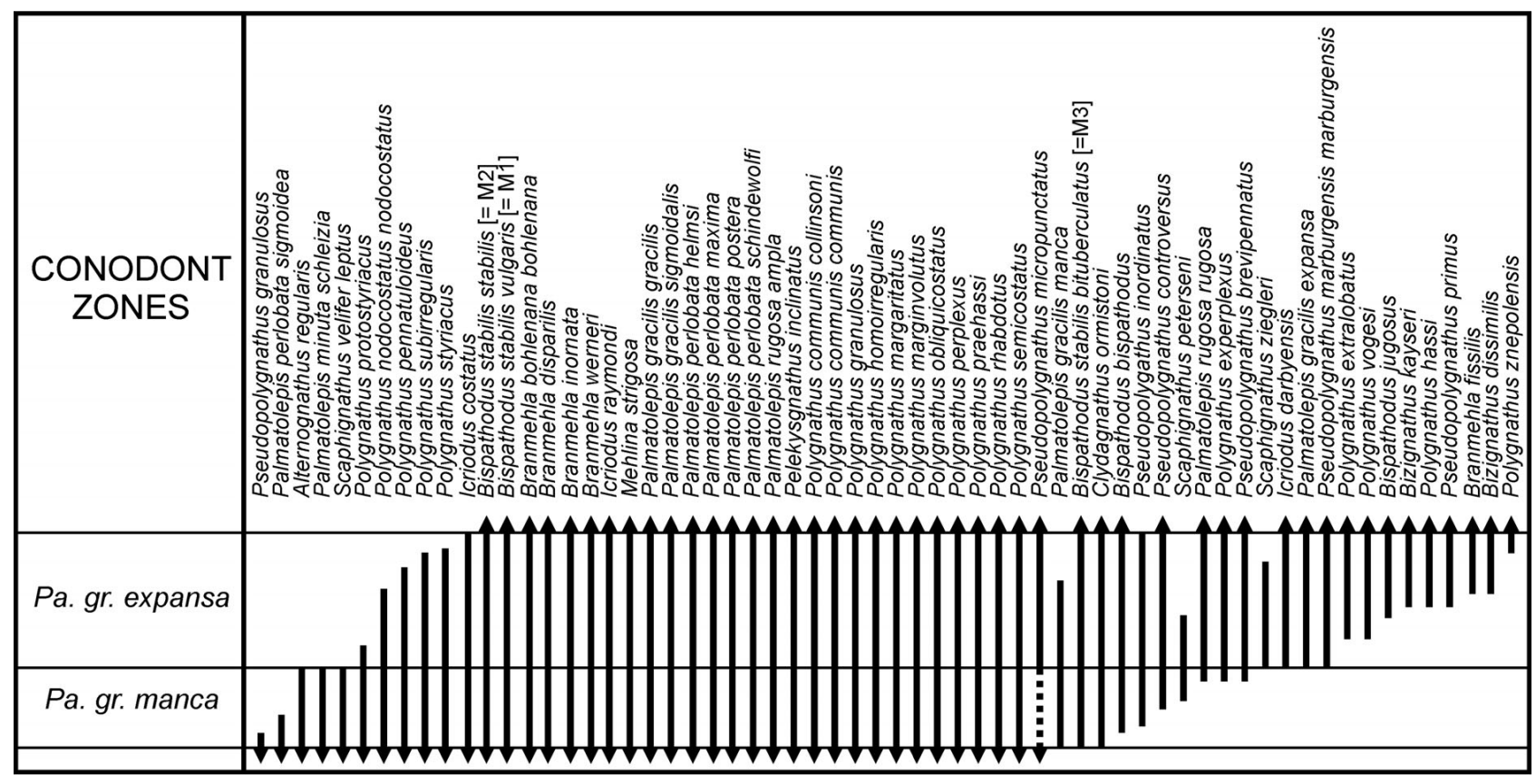

Figure 7. Stratigraphic distribution of the main Famennian conodont species and subspecies from the Palmatolepis gracilis manca Zone to the Palmatolepis gracilis expansa Zone.

Hartenfels (2011) may have local value but it cannot be used in a standard zonation, as in other localities it has a lower entry, e.g. in the Carnic Alps Bispathodus stabilis stabilis has been found in samples attributed to the Pseudopolygnathus granulosus Zone (Perri and Spalletta, unpublished data).

Conodonts useful for the zonal identification. - Icriodus darbyensis, Pseudopolygnathus brevipennatus, and Ps. marburgensis marburgensis have their first appearance at the base of the zone. Scaphignathus ziegleri is limited to this zone. Bispathodus jugosus, Bizignathus dissimilis, Biz. kaiseri, Branmehla fissilis, Polygnathus extralobatus, Po. hassi, Po. vogesi, and Ps. primus enter within the zone, and Po. znepolensis in the uppermost part. The upper part of the zone can be identified by the presence of Branmehla fissilis, Polygnathus hassi and Pseudopolygnathus primus. Polygnathus nodocostatus nodocostatus and Scaphignathus peterseni become extinct within the zone; Icriodus costatus, Polygnathus styriacus, Po. subirregularis, and Pseudopolygnathus inordinatus near or at the top (Fig. 7).

\section{Bispathodus aculeatus aculeatus Zone}

Lower boundary: FAD of Bispathodus aculeatus aculeatus Upper boundary: FAD of Bispathodus costatus

Remarks. - The zone corresponds to the lower part of the Middle expansa Zone. It was proposed by Corradini et al.
(2016). It is equivalent to the lower subzone of the Bispathodus aculeatus aculeatus Zone of Hartenfels (2011).

Conodonts useful for the zonal identification. - Bispathodus aculeatus anteposicornis, Bi. spinulicostatus, and Clydagnathus plumulus first appear at or near the base of the zone. Palmatolepis perlobata helmsi and Palmatolepis gracilis manca become extinct above the base of the zone, Bispathodus stabilis bituberculatus (= Bi. stabilis M3), Bizignathus dissimilis, Branmehla werneri, Clydagnathus ormistoni and Palmatolepis perlobata maxima within the zone (Fig. 8).

\section{Bispathodus costatus Zone}

Lower boundary: FAD of Bispathodus costatus Upper boundary: FAD of Bispathodus ultimus

Remarks. - The zone is equivalent to the upper part of the Middle expansa Zone, and to the Lower costatus Zone of Ziegler (1962). It is the same as proposed by Corradini et al. (2016). It also corresponds to the Bispathodus costatus Subzone of Hartenfels (2011) raised to zonal rank by Corradini et al. (2016).

Conodonts useful for the zonal identification. - Polygnathus spicatus enters within the zone. Polygnathus hassi, Po. rhabdotus, and Pseudopolygnathus controversus become extinct within the zone, Icriodus raymondi, Polygnathus experplexus, Po. homoirregularis, and Po. margaritatus at the top (Fig. 8). 


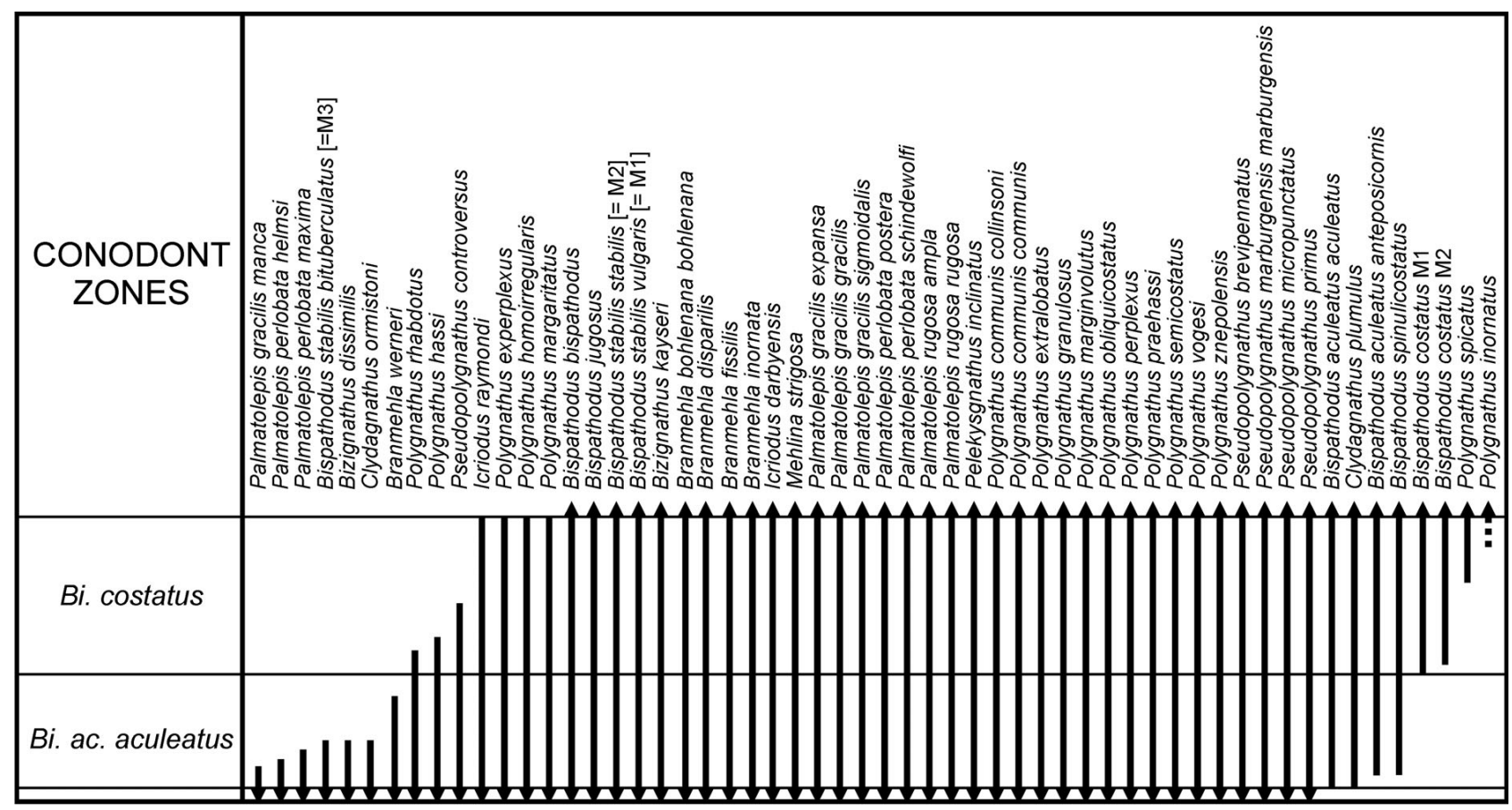

Figure 8. Stratigraphic distribution of the main Famennian conodont species and subspecies from the Bispathodus aculeatus aculeatus Zone to the Bispathodus costatus Zone.

\section{Bispathodus ultimus Zone}

Lower boundary: FAD of Bispathodus ultimus Upper boundary: FAD of Protognathodus kockeli

Remarks. - The re-defined zone is equivalent to the Upper expansa, Lower and Middle praesulcata zones of Ziegler \& Sandberg (1984), as well as to the Upper expansa and praesulcata zones and the costatus-kockeli Interregnum of Kaiser et al. (2009). It corresponds also to the ultimus ultimus and praesulcata zones and costatus-kockeli Interregnum of Becker et al. (2016). The name ultimus Zone was first used regionally in the Pyrenees (Perret 1988), and then adopted internationally in the sense of the Upper expansa Zone by Hartenfels \& Becker (2012). The zone was then re-defined and enlarged by Corradini et al. (2016). It extends for an interval quite long when compared to the other Famennian zones. Here it is not subdivided, as Siphonodella praesulcata, which entry was used by Ziegler \& Sandberg $(1984,1990)$ to define the Lower praesulcata Zone, is a taxon rare and difficult to identify (Kaiser \& Corradini 2011). The occurrence of Si. praesulcata could be useful as an indication of the middle part of the zone, which can be identified by the entry of Protognathodus meischneri and Pr. collinsoni. The lower and middle parts of the zone are characterized by a fauna with high diversity. The upper part, corresponding to the "costatus-kockeli Interregnum" of Kaiser et al. (2009), is characterized by an impoverished fauna following the extinction associated with the Hangen- berg Event. Kononova \& Weyer (2013) named a new subspecies of Bi. ultimus - Bi. ultimus bartzschi but here this subspecies is not considered valid.

Conodonts useful for the zonal identification. - Branmehla suprema, Palmatolepis gracilis gonioclymeniae, and Pseudopolygnathus marburgensis trigonicus enter near the base of the zone; Polygnathus purus purus, and Po. symmetricus enter in the lower part. The first occurrences of the two last species are probably not synchronous worldwide as delayed occurrences are common in the basal Tournaisian. Protognathodus collinsoni, Pr. meischneri, and Siphonodella praesulcata and other early Siphonodella species enter in the middle part of the zone. Polygnathus marginvolutus, Po. perplexus, Po. praehassi, and Peudopolygnathus brevipennatus become extinct in the basal part of the zone. In the middle part of the zone Bizignathus kaiseri, Branmehla bohlenana bohlenana, Br. fissilis, Icriodus darbyensis, Ps. marburgensis marburgensis, and several polygnathids became extinct (see Fig. 9). Bispathodus bispathodus, Bi. costatus, Bispathodus jugosus, Bi. ultimus, Branmehla disparilis, Palmatolepis gracilis expansa, Pa. gracilis gonioclymeniae, and Pseudopolygnathus marburgensis trigonicus disappear in the upper part (Fig. 9). Palmatolepis perlobata postera, Pa. perlobata schindewolfi, Pa. rugosa ampla, $P a$. rugosa rugosa were reported by Ji \& Ziegler (1993) to range to the top of the Upper expansa Zone, but according to Becker et al. (2015) these taxa come only from mixed fauna and the late findings are due to reworking. 


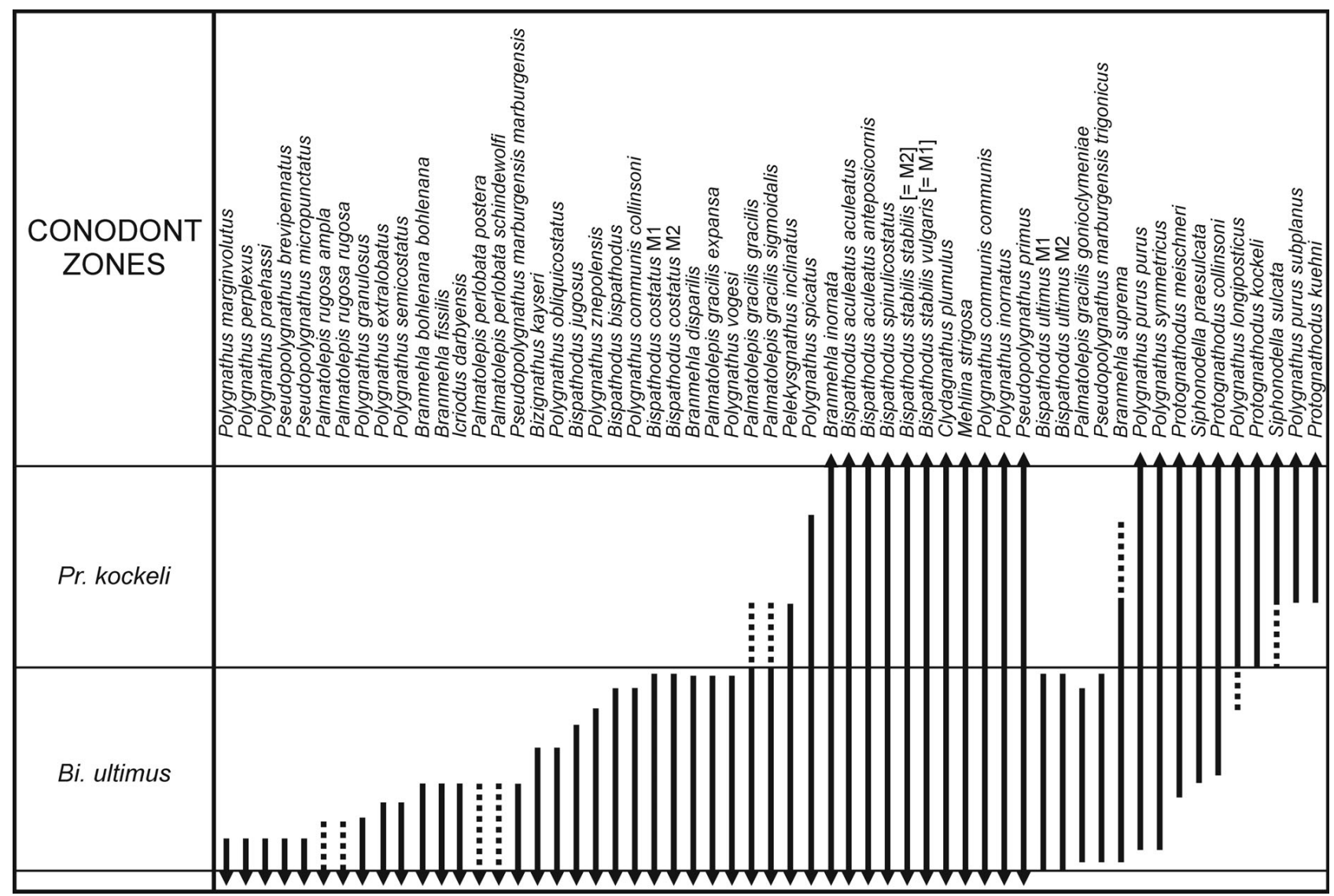

Figure 9. Stratigraphic distribution of the main Famennian conodont species and subspecies from the Bispathodus ultimus Zone to the Protognathodus kockeli Zone.

\section{Protognathodus kockeli Zone}

Lower boundary: FAD of Protognathodus kockeli Upper boundary: FAD of Siphonodella bransoni

Remarks. - The revised zone is equivalent to the Upper praesulcata and sulcata zones of Ziegler \& Sandberg (1984), and to the kockeli and sulcata/kuehni zones of Kaiser et al. (2009). The zone in its present form was proposed by Corradini et al. (2016), which spans from the uppermost part of the Famennian to the lowest part of the Tournaisian, including the present position of the Devonian/Carboniferous Boundary.

Conodonts usefulfor the zonal identification. - Polygnathus purus subplanus, and Protognathodus kuehni enter in the middle part of the zone. Curved elements identified as representatives of Siphonodella sulcata enter within the zone, most likely in the basal part. The stratigraphic position of the entry of typical Siphonodella sulcata is still uncertain. Palmatolepis gracilis gracilis, Pa. gracilis sigmoidalis, the last representatives of the Upper Devonian genus Palmatolepis, Branmehla suprema, and Pelekys- gnathus inclinatus become extinct. Kaiser et al. (2009) suggested that all the occurrences of palmatolepids after the Hangenberg extinction Event are due to reworking, as they have never been found above the level of the extinction in undisturbed sequences. Polygnathus spicatus becomes extinct within the zone. Branmehla inornata becomes extinct within the zone, or possibly it goes higher (Fig. 9).

\section{Acknowledgements}

The first author is deeply indebted with Gilbert Klapper for advice, help and support. We are grateful to Thomas Becker, Sven Hartenfels and Tomás Kumpan for their useful reviews. The study by Carlo Corradini was partly supported by R.A.S. (grants LR7/07 - 2010). This paper is a contribution to IGCP 596 "Mid Palaeozoic climate and biodiversity".

\section{References}

Bahrami, A., Corradini, C., Over, D.J. \& Yazdi, M. 2013. Conodont biostratigraphy of the upper Frasnian-lower Famennian 
transitional deposits in the Shotori Range, Tabas area, Central-East Iran Microplate. Bulletin of Geosciences 88, 369-388. DOI 10.3140/bull.geosci.1353

Bahrami, A., Gholamalian, H., Corradini, C. \& Yazdi, M. 2011. Upper Devonian conodont biostratigraphy of Shams Abad section, Kerman province, Iran. Rivista Italiana di Paleontologia e Stratigrafia 117, 199-209.

BARDASHEVA, N.P., BARDASHEV, I.A., WedDige, K. \& Ziegler, W. 2004. Stratigraphy and conodonts of the Lower Carboniferous of the Shiskat section (southern Tien Shan, Central Tajikistan). Senckenbergiana Lethaea 84, 225-301. DOI 10.1007/BF03043472

Becker, R.T., Gradstein, F.M. \& Hammer, O. 2012. The Devonian Period, 559-601. In Gradstein, F.M., OGG, J.G., Schmitz, M. \& OGg, G. (eds) The Geologic Time Scale 2012, Elsevier, Oxford.

Becker, R.T., Hartenfels, S., Aboussalam, Z.S., Tragelehn, H., Brice, D. \& El Hassani, A. 2013. The Devonian-Carboniferous boundary at Lalla Mimouna (Northern Maider) a progress report, 109-120. In BECKER, R.T., El HASSANI, A. \& TAHIRI, A. (eds) International Field Symposium "The Devonian and Lower Carboniferous of northern Gondwana" - Field Guidebook. Document de l'Institut Scientifique, Rabat 27.

Becker, R.T., Hartenfels, S. \& Weyer, D. 2015. The Famennian to Lower Visean at Drewer (northern Rhenish Massive). Münstersche Forschungen zur Geologie und Paläontologie 108, 122-140.

Becker, R. T., El Hassani, A. \& TAhiRi, A. (eds) 2013. International Field Symposium "The Lower Devonian and Lower Carboniferous of northern Gondwana". International Field Symposium "The Devonian and Lower Carboniferous of northern Gondwana" - Field Guidebook. Document de l'Institut Scientifique, Rabat 27, 1-150.

BeCKer, R.T., KAISER, S.I. \& ARETZ, M. 2016. Review of chrono-, litho- and biostratigraphy across the global Hangenberg Crisis and Devonian-Carboniferous Boundary, 355-386. In BECKER, R.T., Königshof, P. \& BRETT, C.E. (eds) Devonian Climate, Sea Level and Evoltionary Events, Geological Society, London, Special Publications 423. DOI 10.1144/SP423.10

Beinert, R.J., KlapPer, G., SANDberg, C.A \& Ziegler, W. 1971. Revision of Scaphignathus and description of Clydagnathus? ormistoni n.sp. (Conodonta, Upper Devonian). Geologica et Palaeontologica 5, 81-91.

Bischoff, G. 1956. Oberdevonische Conodonten (to I $\delta$ ) aus dem Rheinischen Schiefergebirge. Notizblatt des Hessisches Landesamt für Bodenforschung 84, 115-37.

Bischoff, G. 1957. Die Conodonten-Stratigraphie des rhenoherzynischen Unterkarbons mit Berücksichtigung der Wocklumeria-Stufe und der Devon-Karbon Grenze. Abhandlunghen des Hessisches Landesamt für Bodenforschung, 84, 115-137.

Bischoff, G. \& ZiEGLER, W. 1956. Das Alter der "Urfer Schishten" im Marburger Hinterland nach Conodonten. Notizblatt des Hessisches Landesamt für Bodenforschung 84, 138-169.

BRANSON, E.R. 1934. Conodonts from the Hannibal Formation of Missouri. Missouri University Studies 8, 301-343.

Branson, E.B. \& Mehl, M.G. 1934a. Conodonts from the Grassy Creek shale of Missouri. Missouri University Studies 8, 171-259.
Branson, E.B. \& Mehl, M.G. 1934b. Conodonts from the Bushberg sandstone and equivalent formations of Missouri. Missouri University Studies 4, 265-300.

Bultynck, P. 2003. Devonian Icriodontidae: biostratigraphy, classification and remarks on paleoecology and dispersal. Revista Española de Micropaleontologia 35(3), 295-314.

Capkinoglu, S. 1991. A new Pelekysgnathus species from the Lower Famennian of the Taurides, Turkey. Bollettino della Società Paleontologica Italiana 30, 349-353.

CAPKinoglu, S. 2000. Late Devonian (Famennian) Conodonts from Denizliköyü, Gebze, Kocaeli, Northwestern Turkey. Turkish Journal of Earth Sciences 9, 91-112.

Capkinoglu, S. \& Gedik, I. 2000. Late Devonian conodont fauna of the Gumusali Formation, the Eastern Taurides, Turkey. Turkish Journal of Earth Sciences 9, 69-89.

Casier, J.G., Lethiers, F. \& Préat, A. 2002. Ostracods and sedimentology of the Devonian-Carboniferous stratotype section (La Serre, Montagne Noire, France). Bulletin de l'Institut Royal des Sciences Naturelles de Belgique, Science de la Terre 72, 43-68.

Cooper, C.L. 1931. New conodonts from the Woodford Formation of Oklahoma. Journal of Paleontology 5(3), 230-243.

Corradini, C. 1998. New Devonian (Famennian) taxa of Polygnathids and Icriodids (Conodonts) from Sardinia. Giornale di Geologia 60, 89-92.

Corradini, C. 2003. Late Devonian (Famennian) conodonts from the Corona Mizziu sections near Villasalto (Sardinia, Italy). Palaeontographia Italica 98, 65-116.

Corradini, C. 2008. Revision of Famennian-Tournaisian (Late Devonian-Early Carboniferous) conodont biostratigraphy of Sardinia, Italy. Revue de Micropaleontologie 51, 123-132. DOI 10.1016/j.revmic.2007.02.005

Corradini, C., Barca, S. \& Spalletta, C. 2003. Late Devonian-Early Carboniferous conodonts from the "Clymeniae limestones" of SE Sardinia (Italy). Courier Forschungsinstitut Senckenberg 245, 227-253.

Corradini, C., Kaiser, S.I., Perri, M.C. \& Spalletta, C. 2011. Protognathodus (Conodonta) and its potential as a tool for defining the Devonian/Carboniferous boundary. Rivista Italiana di Paleontologia e Stratigrafia 117, 15-28.

Corradini, C., Spalletta, C., Kaiser, S.I. \& Matyja, H., 2013. Overview of conodonts across the Devonian/Carboniferous boundary. Asociación Paleontológica Argentina, Publicación Especial 13, 13-16.

Corradini, C., Spalletta, C., Mossoni, A., Matyja, H. \& Over, D.J. 2016. Conodont across the Devonian/Carboniferous boundary: a review and implication for the redefinition of the boundary and a proposal for an updated conodont zonation. Geological Magazine, 1-15. DOI 10.1017/S001675681600039X

Dreesen, R. \& Dusar, M. 1974. Refinement of conodont-biozonation in the Famenne area, 1-38. In BoucKaerT, J.P. \& STREet, M. (eds) International Symposium on Belgian Micropalaeontological Limits, Namur 1974. Geological Survey of Belgium Publication 13.

Druce, E.C. 1969. Devonian and Carboniferous conodonts from Bonaparte Gulf Basin, Northen Australia. Bureau of Mineral Resources, Geology and Geophysics Bulletin 69, 1-243.

DruCE, E.C. 1976. Conodont biostratigraphy of the Upper 
Devonian reef complexes of the Canning Basin, western Australia. Australian Bureau of Mineral Resources, Geology and Geophysics, Bulletin 158, 1-303.

DzIK, J. 2006. The Famennian "Golden Age" of conodonts and ammonoids in the Polish part of the Variscan Sea. Palaeontologia Polonica 63, 1-360.

FlÜGEL, H. \& ZIEGLER, W. 1957. Die Gliederung des Oberdevons und Unterkarbons am Steinberg westlich von Graz mit Conodonten. Mitteilungen des Naturwissenschaftischen Vereines für Steinmark 87, 25-60.

GAtovsky, Y.A. 2008. New Species of Antognathus (Conodonts) from the Famennian Deposits of Southern Kazakhstan. Palaeontological Journal 42(2), 176-180.

Gatovsky, Y.A. 2009. New Genera Barskovella \& Bizignathus (Conodonts) from the Famennian of Southern Kazakhstan. Palaeontological Journal 43(5), 550-557. DOI 10.1134/S0031030109050116

Gedik, I. 1969. Karnik Alpler'den Alt Karbonifer'e ait Conodont'lar. The Mineral research and Exploration Institut of Turkey, Bulletin 70, 229-242.

Girard, C., Cornée, J.J., Charrault, A.L., Corradini, C., Weyer, D., Bartzsch, K., Joachimski, M. \& Feist, R. 2017. Conodont biostratigraphy and paleoenvironmental trends during the Famennian (Late Devonian) in the Thuringian Buschteich section (Germany). Newsletter on Stratigraphy 50(1), 71-89. DOI 10.1127/nos/2016/0318

Girard, C., Cornée, J.J., Corradini, C., Fravalo, A. \& Feist, R. 2014. Paleoenvironmental changes at $\mathrm{Col}$ des Tribes (Montagne Noire, France), a reference section for the Famennian of north Gondwana-related areas. Geological Magazine 151, 864-884. DOI 10.1017/S0016756813000927

Girard, C., Klapper, G. \& Feist, R. 2005. Subdivision of the terminal Frasnian linguiformis conodont Zone, revision of the correlative interval of Montagne Noire Zone 13, and discussion of stratigraphically significant associated trilobites, 181-198. In Over, D.J., Morrow, J.R. \& Wignall, P.B. (eds) Understanding Late Devonian and Permian-Triassic Biotic and Climatic Events: Towards an Integrated Approach, Developments in Palaeontology and Stratigraphy 20, Elsevier, Amsterdam.

Glenister, B.F. \& Klapper, G. 1966. Upper Devonian conodonts from the Canning Basin, Western Australia. Journal of Paleontology 40, 777-842.

Han, Y. 1987. Study on Upper Devonian Frasnian/Famennian boundary in Ma-Anshan, Zhongping, Xiangzhou, Guangxi. Chinese Academy of Geological Sciences Bulletin 17, 171-194.

HartenfELS, S. 2011. Die globalen Annulata-Events und die Dasberg-Krise (Famennium, Oberdevon) in Europa und Nord-Afrika: hochauflösende Conodonten-Stratigraphie, Karbonat-Mikrofazies, Paläoökologie und Paläodiversität. Münstersche Forschungen zur Geologie und Paläontologie 105, 17-527.

Hartenfels, S. \& BeCKER, R.T. 2012. Conodont age and correlation of the transgressive Gonioclymenia and Calloclymenia Limestones (Famennian, Anti-Atlas, SE Morocco). Centenary Meeting of the Paläontologische Gesellschaft, At Museum für Naturkunde Berlin, Abstract Volume, Terra Nostra 2012/3, 67.
Hartenfels, S. \& Becker, R.T. 2016. The global Annulata Events: review and new data from the Rheris Basin (northern Tafilalt) of SE Morocco, 291-354. In BECKER, R.T., Königshof, P. \& Brett, C.E. (eds) Devonian Climate, Sea Level and Evolutionary Events. Geological Society, London, Special Publications, 423. DOI 10.1144/SP423.14

Hass, W.H. 1959. Conodonts from the Chappel Limestone of Texas. U.S. Geological Survey professional paper 294, 365-399.

Helms, J. 1959. Conodonten aus dem Saalfelder Oberdevon (Thuringen). Geologie 8, 634-677.

Helms, J. 1961. Die "nodocostata-Gruppe" der Gattung Polygnathus. Geologie 10(6), 674-711.

Helms, J. 1963. Zur "Phylogenese" und Taxionomie von Palmatolepis (Conodontida, Oberdevon). Geologie 12(4), 449-485.

Helms, J. \& WolsKa, Z. 1967. New Upper Devonian conodonts from Poland and Germany. Acta Paleontologica Polonica 12(2), 227-238.

Holmes, G.B. 1928. A bibliography of the conodonts with descriptions of early Mississippian species. U. S. Natural Museum Proceeding 72, 1-38. DOI 10.5479/si.00963801.72-2701.1

House, M.R., Becker, R.T., Feist, R., Flajs, G., Girard, C. \& KLAPPER, G. 2000. The Frasnian/Famennian boundary GSSP at Coumiac, Southern France. Courier Forschungsinstitut Senckenberg 225, 59-75.

Huang, C. \& Gong, J. 2016. Timing and patterns of the Frasnian-Famennian event: Evidences from high-resolution conodont biostratigraphy and event stratigraphy at the Yangdi section, Guangxi, South China. Palaeogeography, Palaeoclimatology, Palaeoecology 448, 317-338. DOI 10.1016/j.palaeo.2015.10.031

HudDLE, J.W. 1934. Conodonts from the New Albany Shale of Indiana. Bullettin American Paleontology 21(72), 1-136.

JI, Q. \& ZiEGLER, W. 1993. The Lali section: an excellent reference section for Late Devonian in south China. Courier Forschungs-Institut Senckenberg 157, 1-183.

Johnson, J.G. 1992. Belief and reality in biostratigraphic zonation. Newsletter on Stratigraphy 26, 41-48. DOI 10.1127/nos/26/1992/41

KAISER, S.I. 2005. Mass extinctions, climatic and oceanographic changes at the Devonian-Carboniferous boundary. $156 \mathrm{pp}$. Ph.D. thesis, Ruhr-University, Bochum, Germany.

KAISER, S.I. 2009. The Devonian/Carboniferous boundary stratotype section (La Serre, France) revisited. Newsletter on Stratigraphy 43(2), 195-205.

DOI 10.1127/0078-0421/2009/0043-0195

Kaiser, S.I., AretZ, M. \& Becker, R.T. 2015. The global Hangenberg Crisis (Devonian-Carboniferous transition): review of a first-order mass extinction, 387-437. In BECKER, R.T., Königshof, P. \& BRetT, C.E. (eds) Devonian Climate, Sea Level and Evolutionary Events, Geological Society, London, Special Publications 423. DOI: 10.1144/SP423.9

Kaiser, S.I., Becker, R.T., Spalletta, C. \& Steuber, T. 2009. High-resolution conodont stratigraphy, biofacies and extinctions around the Hangenberg Event in pelagic successions from Austria, Italy and France. Palaeontographica Americana 63, 97-139. 
Kaiser, S. \& Corradini, C. 2008. Should the Devonian/Carboniferous Boundary be redefined? Newsletter SDS 23, 55-56.

Kaiser, S. \& Corradini, C. 2011. The early Siphonodellids (Conodonta, Late Devonian-Early Carboniferous): overview and taxonomic state. Neues Jahrbuch für Geologie und Paläontologie Abhandlungen 261, 19-35.

DOI 10.1127/0077-7749/2011/0144

Kalvoda, J. \& KuKaL, Z. 1987. Devonian-Carboniferous Boundary in the Moravian Karst at Lesní lom, Brno-Líšeň, Czechoslovakia. Courier Forschungsinstitut Senckenberg 98, 95-117.

Kalvoda, J., Kumpan, T. \& BÁBeK, O. 2015. Upper Famennian and Lower Tournaisian sections of the Moravian Karst (Moravo-Silesian Zone, Czech Republic): a proposed key area for correlation of the conodont and foraminiferal zonations. Geological Journal 50, 17-38. DOI 10.1002/gj.2523

Khalymbadzha, V.G., Shinkaryov, Y. \& Gatovsky, Y.A. 1992. New Famennian polygnathids (conodonts) from southern Kazakhstan. Palaeontological Journal 25, 69-81.

KLAPPER, G. 1958. An Upper Devonian conodont fauna from the Darby Formation of the Wind River Mountains, Wyoming. Journal of Paleontology 32, 1082-1093.

KLAPPER, G. 1989. The Montagne Noire Frasnian (Upper Devonian) conodont succession, 449-468. In McMillan, N.J., Embry, A. \& Glass, D.J. (eds) Devonian of the World, Canadian Society of Petroleum Geologists Memoir 14(III).

KLAPPER, G. 1991. Accuracy of biostratigraphic zones. Palaios 6, 1. DOI $10.2307 / 3514949$

KLAPPER, G. 1997. Graphic correlation of Frasnian (Upper Devonian) sequences in Montagne Noire, France, and western Canada, 113-129. In Klapper, G., Murphy, M.A. \& TAlent, J.A. (eds) Paleozoic Sequence Stratigraphy, Biostratigraphy, and Biogeography: Studies in Honor of J. Granville ("Jess") Johnson, Geological Society of America Special Paper 321.

KLAPPER, G. 2007a. Frasnian (Upper Devonian) conodont succession at Horse Spring and correlative sections, Canning Basin, Western Australia. Journal of Paleontology 81(3), 513-537. DOI 10.1666/05088.1

KLAPPER, G. 2007b. Conodont taxonomy and the recognition of the Frasnian/Famennian (Upper Devonian) Stage Boundary. Stratigraphy 4(1), 67-76.

KlAPPER, G. \& BECKER, R.T. 1999. Comparison of Frasnian (Upper Devonian) Conodont Zonations. Bollettino della Società Paleontologica Italiana 37, 339-348.

KLAPPER, G. \& Foster, C.T. JR. 1993. Shape analysis of Frasnian species on the Late Devonian conodont Genus Palmatolepis. The Paleontological Society Memoir 32, 1-35.

KlapPer, G. \& ZiegleR, W. 1979. Devonian conodont biostratigraphy,199-224. In House, M.R., Scrutton, C.T. \& Bassett, M.G. (eds) The Devonian System. Special Papers in Paleontology 23.

Klapper, G., Feist, R. \& Becker, R.T. 1994. Definition of the Frasnian/Famennian Stage boundary. Episodes 16(4), 433-441.

Klapper, G., KuZ'min, A. V. \& Ovnatanova, N. S. 1996. Upper Devonian conodonts from the Timan-Pechora region, Russia, and correlation with a Frasnian composite standard. Journal of Paleontology 70, 131-152.

DOI 10.1017/S0022336000023179
Klapper, G., Uyeno, T.T., Armstrong, D.K. \& Telford, P. G. 2004. Conodonts of the Williams Island and Long Rapids formations (Upper Devonian, Frasnian-Famennian) of the Onakawana B Drillhole, Moose River Basin, northern Ontario, with a revision of Lower Famennian species. Journal of Paleontology 78, 371-387.

DOI 10.1666/0022-3360(2004)078<0371:COTWIA>2.0.CO;2

Koch, M., LeuteritZ, K. \& Ziegler, W. 1970. Alter, Fazies und Paläographie der Oberdevon/Unterkarbon-Schichtenfolge am der Seilerbei Iserlohn. Fortschritte in der Geologie Rheinland und Westfalen 17, 679-732.

Kononova, L.I. \& Weyer, D. 2013. Upper Famennian conodonts from the Breternitz Member (Upper Clymeniid Beds) of the Saalfeld region, Thuringia (Germany). Freiberger Forschungshefte C 545, 15-97.

Korn, D. \& Luppold, F.W. 1987. Nach Clymenien und Conodonten gegliederte Profile des oberen Famennium im Rheinischen Schiefergebirge. Courier Forschunginstitut Senckenberg 92, 199-223.

Kozitskaya, R.I., Koskenko, Z.A., Lipnyagov, O.M. \& NemiROVSKAYA, T.I. 1978. Conodonts from the Carboniferous of the Donets Basin. 133 pp. Institut Geologichekikh Nauk, Akademiya Nauk Ukrainskoy SSR, Naukova Dumka, Kiev. [in Russian]

Kronberg, P., Pilger, A., Scherp, A. \& Ziegler W. 1960. Spuren altvaristischer Bewegungen in nordöstlichen Teil des Rheinischen Schiefergebirges. Fortschritte in der Geologie Rheinland und Westfalen 3(1), 1-46.

Kumpan, T., Bábek, O., Kalvoda, J., Grygar, T.M. \& Frýda, J. 2014. Sea-level and environmental changes around the Devonian-Carboniferous boundary in the Namur-Dinant Basin (S Belgium, NE France): A multi-proxy stratigraphic analysis of carbonate ramp archives and its use in regional and interregional correlations. Sedimentary Geology 311, 43-59. DOI 10.1016/j.sedgeo.2014.06.007

Kürschner, W., Becker, R.T., Buhl, D. \& Veizer, J. 1993. Strontium isotopes in conodonts: Devonian-Carboniferous transition, the Northern Rhenish Slate Mountains, Germany. Annales de la Société géologique de Belgique 115(2), 595-621.

KuZ'Min, A.V. 1990. Asimmetricheskiye pary platformennykh elementov u nekotorykh predstaviteley roda Polygnathus (konodonty). Paleontologicheskii Zhurnal 4, 66-74. [in Russian]

LANE, H.R., SANDBerg, C.A. \& Ziegler, W. 1980. Taxonomy and phylogeny of some Lower Carboniferous conodonts and preliminary standard post-Siphonodella zonation. Geologica et Palaeontologica 14, 117-164.

Malec, J. 2014. The Devonian/Carboniferous boundary in the Holy Cross Mountains (Poland). Geological Quarterly 58, 217-234. DOI 10.7306/gq.1142

MatyjA, H. 1972. Biostratygrafia dewonu gornego z profilu wiercenis Chojnice 2 (Pomorze Zachodnie). Acta Geologia Polonica 22, 735-750.

Matyja, H. 1993. Upper Devonian of Western Pomerania. Acta Geologica Polonica 43(1-2), 27-94.

Matyja, H., Sobien, K., Marynowski, L., Stempien-SaŁeK, M. \& Małkowski, K. 2015. The expression of the Hangenberg Event (latest Devonian) in a relatively shallow-marine succession 
(Pomeranian Basin, Poland): the results of a multi-proxy investigation. Geological Magazine 152, 400-428. DOI 10.1017/S001675681400034X

MetzGer, R.A. 1994. Multielement reconstructions of Palmatolepis and Polygnathus (Upper Devonian, Famennian) from the Canning Basin, Australia, and Bactrian Mountain, Nevada. Journal of Paleontology 68(3), 617-647. DOI 10.1017/S0022336000025956

Molloy, P.D., Talent, J.A. \& Mawson, R. 1997 Late Devonian Tournaisian conodonts from the eastern Khyber region, north-west Pakistan. Rivista Italiana di Paleontologia $e$ Stratigrafia 103, 123-148.

Mossoni, A., 2014. Selected Famennian (Late Devonian) events (Condroz, Annulata, Hangenberg) in Sardinia and in the Carnic Alps: conodont biostratigraphy, magnetic susceptibility and geochemistry. 171 pp. Ph.D. thesis, Università di Cagliari, Cagliari, Italy.

Mossoni, A., Carta, N., Corradini, C. \& Spalletta, C. 2015. Conodonts across the Devonian/Carboniferous boundary in SE Sardinia (Italy). Bulletin of Geosciences 90, 371-388. DOI 10.3140/bull.geosci.1524

MülLER, K.J. 1956. Zur Kenntnis der Conodonten-Fauna des europaischen Devons, 1; Die Gattung Palmatolepis. Abhandlunghen and Senckenbergischen Naturforschenden Gesellschaft 494, 1-70.

Murphy, M.A. 1994. Fossils as a basis for chronostratigraphic interpretation. Neues Jahrbuch für Geologie und Paläontologie, Abhandlungen 192, 255-271.

Over, D.J. 1992. Conodonts and the Devonian-Carboniferous boundary in the Upper Woodford Shale, Arbuckle Mountains, South-Central Oklahoma. Journal of Paleontology 66, 293-311. DOI 10.1017/S0022336000033801

Over, D. J. 2007. Conodont biostratigraphy of the Chattanooga Shale, Middle and Upper Devonian, southern Appalachian Basin, eastern United States. Journal of Paleontology 81, 1194-1217. DOI 10.1666/06-056R.1

Over, D.J., Lazar, R., Baird, G.C., Schieber, J. \& EtTEnsohn, F.R. 2009. Protosalvinia Dawson and associated conodonts of the Upper trachytera Zone, Famennian, Upper Devonian, in the Eastern United States. Journal of Paleontology 83, 70-79. DOI 10.1017/S0022336000058133

Ovnatanova, N.S. 1969. Novye verkhnedevonskie konodonty tsentralnykh rayonov Russkoy Platformy in Timana. Fauna i Stratigraphiya Paleozoya Russkoy Platformy, 39-141. [in Russian]

Owen, D.E. 1987. Commentary: Usage of stratigraphic terminology in papers, illustrations, and talks. Stratigraphy 6, 106-116.

OwEn, D.E. 2009. How to use of stratigraphic terminology in papers, illustrations, and talks. Journal of Sedimentary Petrology 57, 363-372.

Paproth, E., Feist, R. \& Flajs, G. 1991. Decision on the Devonian-Carboniferous boundary stratotype. Episodes 14, 331-336.

Perri, M.C. \& Spalletta, C. 1990. Famennian conodonts from climenid pelagic limestone, Carnia Alps, Italy. Palaeontographia Italica 77, 55-83.

Perri, M.C. \& Spalletta, C. 1991. Famennian conodonts from Cava Cantoniera and Malpasso sections, Carnic Alps, Italy. Bollettino della Società Paleontologica Italiana 30, 47-78.
Perri, M.C. \& Spalletta, C. 1998a. Latest Devonian and Early Carboniferous conodonts from the Casera Collinetta di Sotto A section (Carnic Alps, Italy). In Perri, M.C. \& Spalletta, C. (eds) Southern Alps Field Trip Guidebook, ECOS VII, Giornale di Geologia 60,168-181.

Perri, M.C. \& Spalletta, C. 1998b. Late Famennian conodonts from the Casera Collinetta di Sotto B section (Carnic Alps, Italy). In Perri, M.C. \& Spalletta, C. (eds) Southern Alps Field Trip Guidebook, ECOS VII, Giornale di Geologia 60, 158-167.

Perri, M.C. \& Spalletta, C., 1998c. The Upper marginifera Zone (Late Devonian) in the Casera Collinetta di Sotto C section (Carnic Alps, Italy). In Perri, M.C. \& Spalletta, C. (eds) Southern Alps Field Trip Guidebook, ECOS VII, Giornale di Geologia 60, 150-157.

Perri, M.C. \& Spalletta, C. 2000. Devonian-Early Carboniferous transgressions and regressions in the Carnic Alps (Italy). Record of the Western Australian Museum, Suppl. 58, 305-319.

Perri, M.C., \& Spalletta, C. 2001. Hangenber Event al limite Devoniano/Carbonifero al Monte Zermula, Alpi Carniche, Italia. In Perri, M.C. (ed.) Giornate di Paleontologia 2001, Giornale di Geologia Serie 3 a 62(2000), Supplemento, 31-40.

Perret, M.F. 1988. Le passage du Devonién au Carbonifére dans les Pyrenées, Zonation par conodontes. Courier Forschungsinstitut Senckenberg 100, 39-52.

Rhodes, F.H.T., Austin, R.L. \& Druce, E.C. 1969. British Avonian (Carboniferous) conodont faunas and their value in local and intercontinental correlation. Bulletin British Museum of Natural History (Geology), Supplement 5, 1-313.

SANDBERG, C.A. 1979. Devonian and Lower Mississippian conodont zonation of the Great Basin and Rocky Mountains, 87-106. In SAndBerg, C.A. \& Clark, D.L. (eds) Conodont biostratigraphy of the Great Basin and Rocky Mountains, Brigham Young University Geology Studies 26(3).

SANDBERG, C.A. \& Dreesen, R. 1984. Late Devonian icriodontid biofacies models and alternate shallow water conodont zonation, 143-178. In CLARK, D.L. (ed.) Conodont biofacies and provincialism. Geological Society of America Special Paper 196. DOI 10.1130/SPE196-p143

SANDBERG, C.A. \& ZiEgLER, W. 1973. Refinement of standard Upper Devonian conodont zonation based on sections in Nevada and West Germany. Geologica et Palaeontologica 7, 97-122.

SANDBERG, C.A. \& ZiEgleR, W. 1979. Taxonomy and biofacies of important conodonts of Late Devonian styriacus-Zone, United States and Germany. Geologica et Palaeontologica 13, 173-212.

SAndberG, C.A., Ziegler, W. \& Bultynck, P. 1989. New standard conodont zones and early Ancyrodella phylogeny across the Middle-Upper Devonian boundary. Courier Forschungsinstitut Senckenberg 110, 195-230.

SAndBerg, C.A., Ziegler, W., Dreesen, R. \& Butler, J.L. 1988. Late Frasnian mass extinction; conodont event stratigraphy, global changes, and possible causes, 263-307. In ZIEGLER, W. (ed.) 1st International Senckenberg Conference and 5th European Conodont Symposium (ECOS V), Contribution 1, Courier Forschungs-Institut Senckenberg 102.

SANDBerg, C.A., Ziegler, W., Leuteritz, K. \& Brill, S.M. 1978. Phylogeny, speciation and zonation of Siphonodella (Conodonta, Upper Devonian and Lower Carboniferous). 
Newsletters on Stratigraphy 7, 102-120.

DOI 10.1127/nos/7/1978/102

Sannemann, D. 1955a. Oberdevonische Conodonten (to II). Senckenbergiana lethaea 36, 123-156.

SANNEMANN, D. 1955b. Beitrag zur untergliederung des Oberdevons nach Conodonten. Neues Jahrbuch für Geologie und Paläontologie, Abhandlungen 100, 324-331.

SAvage, N.M. 2013. Late Devonian Conodonts from northwestern Thailand. 48pp. Bourland Printing, A Trinity Press Company, Eugene.

SCHÄFER, W. 1976. Einige neue Conodonten aus dem höheren Oberdevon des Sauerlandes (Rheinisches Schiefergebirge). Geologica et Palaeontologica 10, 141-152.

SCHÜLKe, I. 1995. Evolutive Prozesse bei Palmatolepis in der frühen Famenne-Stufe (Conodonta, Ober-Devon). Göttinger Arbeiten zur Geologie und Paläontologie 67, 1-108.

SCHÜLKE, I. 1996. Evolution of early Famennian ancyrognathids (Conodonta, Late Devonian). Geologica et Palaeontologica 30, 33-47.

SCHÜLKE, I. 1998. Conodont community structure around the Kellwasser mass extinction event (Frasnium/Famennium boundary interval). Senckenbergiana lethaea 77, 87-99.

SCHÜLKE, I. 1999. Conodont multielement reconstruction from the Early Famennian (Late Devonian) of the Montagne Noire (Southern France). Geologica et Palaeontologica SB 3, 1-123.

Sсотт, A.J. 1961. Three new conodonts from the Lousiana Limestone (Upper Devonian) of western Illinois. Journal of Paleontology 35, 1225-1227.

Spalletta, C. \& Perri, M.C. 1994. Associazioni rimaneggiate a conodonti in calcari micritici del Tournaisiano superiore (Alpi Carniche): implicazioni sedimentologiche e paleoambientali. Paleopelagos 3(1993), 145-157.

Spalletta, C., Perri, M.C. \& Pondrelli, M. 1998. Late Famennian conodonts from the Rio Boreado section (Carnic Alps, Italy), 214-219. In Perri, M.C. \& Spalletta, C. (eds) Southern Alps Field Trip Guidebook, ECOS VII, Giornale di Geologia 60.

Spassov, C. 1965. Das Karbonatische Oberdevon in Kraiste und seine Conodontenfauna. Travaux sur la Géologie de Bulgarie, Série Paléontologie 7, 71-113.

Szulczewski, M. 1971. Upper Devonian conodonts, stratigraphy and facial development in the Holy Cross Mts. Acta Geologica Polonica 21(1), 1-130.

Thомаs, L.A. 1949. Devonian-Mississippian Formations of southeast Iowa. Bulletin of the Geological Society of America 60, 403-138.

DOI 10.1130/0016-7606(1949)60[403:DFOSI]2.0.CO;2

TrageleHn, H. 2010. Short note on the origin of the conodont Genus Siphonodella in the Uppermost Famennian. SDS Newsletter 25, 41-43.

Tragelehn, H. \& Hartenfels, S. 2011. Neue Conodont taxa aus dem höheren Famennium (Oberdevon) des Frankenwaldes. Münstersche Forschungen zur Geologie and Paläontologie 105, 1-15.

Ulrich, E.O. \& BASSLER, R.S. 1926. A classification of the tooth-like fossils, conodonts, with descriptions of American Devonian and Mississippian species. Proceedings of the United States National Museum 68, 1-63. DOI 10.5479/si.00963801.68-2613.1
Voges, A. 1959. Conodonten aus dem Unterkarbon I and II (Gattendorfia und Pericyclus-Stufe) des Sauerlandes. Paläontologische Zeitschrift 3, 266-314.

DOI 10.1007/BF02987939

Vorontsova, T.N. 1993. The genus Polygnathus sensu lato (Conodonta): phylogeny and systematics. Palaeontological Journal 27(3), 83-99.

Vorontsova, T.N. \& KuZ'Min, A.V. 1994. The Distribution of New Conodont Species of the Genus Polygnathus in the Famennian Deposits of Central Kazakhstan. Izvestija Akademii Nauk SSSR, Ser. geol. 10, 58-64.

WANG, C.Y.\& YIN, B.A. 1988. Conodonts, 105-148. In Yu, C.M. ET AL. (eds), Devonian-Carboniferous boundary in Nanbiancun Guilin, Science Press, Beijing.

Wang, Z.H., Becker, R.T., Aboussalam, Z.S., Hartenfels, S., JoACHIMSKI, M.M. \& Gong, Y.M. 2016. Conodont and carbon isotope stratigraphy near the Frasnian/Famennian (Devonian) boundary at Wulankeshun, Junggar Basin, NW China. Palaeogeography, Palaeoclimatology, Palaeoecology 448, 279-297. DOI 10.1016/j.palaeo.2015.12.029

WitZKe, B.J., BunKER, B.J. \& Rogers, F.S. 1989. Eifelian through Lower Frasnian stratigraphy and deposition in the Iowa area, Central Midcontinent, U.S.A. Canadian Society Petroleum Geology Memoir 14(I), 221-250.

YAZDI, M. 1999. Late Devonian-Carboniferous conodonts from Eastern Iran. Rivista Italiana di Paleontologia e Stratigrafia 105, 167-200.

Youngquist, W.L. \& Peterson, R.F. 1947. Conodonts from the Sheffield Formation of north-central Iowa. Journal of Paleontology 21, 242-253.

Zhuravlev, A.V., 1991. A new Polygnathus species (Conodonta) from the Lower Carboniferous of the North Urals. Paleontologicheskii Zhurnal 1, 129-130. [in Russian]

ZIEGLER, W. 1958. Conodonten-feinstratigraphische Untersuchungen an der Grenze Mitteldevon/Oberdevon und in der Adorfstufe. Notizblatt des Hessisches Landesamt für Bodenforschung 87, 7-77.

ZiEGLER, W. 1959. Conodonten aus Devon und Karbon Südwesteuropas und Bemerkungen zur bretonischen Faltung (Montagne Noire, Massiv Mouthoumet, Span. Pyrenäen). Neues Jahrbuch für Geologie und Paläeontologie, Monatshefte, 289-309.

ZIEGLER, W. 1962a. Taxionomie und Phylogenie Oberdevonischer Conodonten und ihre stratigraphische Bedeutung. Abhandlunghen des Hessisches Landesamt für Bodenforschung 38, 1-166.

ZiegleR, W. 1962b. Die Conodonten aus den Geröllen des Zechsteinkonglomerates von Rossenray (südwestlisch Rheinberg/Niederrhein). Fortschritte in der Geologie von Rheinland und Westfalen 6, 391-406, pre-print 1960.

ZIEGLER, W. 1969. Eine neue Conodontenfauna aus dem höchsten Oberdevon. Fortschritte Geologie von Rheinland und Westfalen 17, 179-191.

ZIEGLER, W. 1971. Conodont stratigraphy of the European Devonian. Geological Society of America Memoirs 127, 67-99.

ZIEGLER, W. (ed.) 1975. Catalogue of conodonts, Volume 2. 404 pp. Schweizerbart'sche Verlagsbuchhandlung, Stuttgart.

ZIEGLER, W. (ed.) 1981. Catalogue of conodonts, Volume 4. 445 pp. Schweizerbart'sche Verlagsbuchhandlung, Stuttgart. Ziegler, W. \& Huddle, J.W. 1969. Die Palmatolepis glabra- 
Gruppe (Conodonta) nach der Revision der Typen von Ulrich \& Bassler durch J. W. Huddle. Fortschritte in der Geologie von Rheinland und Westfalen 16, 377-386.

Ziegler, W. \& SANDBerg, C.A. 1984. Palmatolepis-based revision of upper part of standard Late Devonian conodont zonation, 179-194. In CLARK, D.L. (ed.) Conodont biofacies and provincialism, Geological Society of America Special Paper 196.

Ziegler, W. \& SANDBERG, C.A. 1990. The Late Devonian Standard Conodont Zonation. Courier Forschungsinstitut Senckenberg 121, 1-115.
Ziegler, W. \& SAndberg, C.A. 1994. Conodont phylogenetic-Zone concept. Newsletter on Stratigraphy 30, 105-123. DOI 10.1127/nos/30/1994/105

Ziegler, W. \& SANDBerg, C.A. 1996. Reflections on Frasnian and Famennian Stage boundary decisions as a guide to future deliberations. Newsletters on Stratigraphy 33, 157-180.

Ziegler, W., Sandberg, C.A. \& Austin, R.L. 1974. Revision of Bispathodus group (Conodonta) in the Upper Devonian and Lower Carboniferous. Geologica et Palaeontologica 8, 97-112.

\section{Appendix}

Table 1. Stratigraphic distribution of common and widespread Famennian conodont species and subspecies. Biostratigraphic range is based on the lowest- and highest occurrence that has been reported for the taxon with the relevant citation. Notes: 1 - The reported range corresponds to that of typical Pa. glabra pectinata, M2 according to Hartenfels (2011); 2 - The reported range corresponds to that of typical Pa. glabra prima, M3 according to Hartenfels (2011); 3, 4- The question mark for the upper range indicates that occurrences of the species after the Hangenberg extinction event may be due to reworking; 5, 12,16 - According to Hartenfels (2011) the species does not reach the top of the Ps. granulosus Zone; 6 - Metzger (1994) lowered the range of Pa.p. maxima to a "generic" rhomboidea Zone but in his sections it occurs above the disappearance of Pa. poolei, therefore we suppose its entry is within the Upper rhomboidea Zone; 7, 8, 10, 11 - The upper range of the species reported by Ji \& Ziegler (1993) is not supported by undoubted evidences (see text for comment); 9 - Here with Pa. quadrantinodosalobata M2 we refer to the typical forms; 13 - According to Hartenfels (2011) the upper range may extend to the Middle expansa Zone; 14 - The given range refers to typical forms of Po. procerus according to the holotype; 15 - This species was defined by Ziegler (1962b, pre-print 1960) as Polylophodonta? triphyllata but before the paper was published Helms (1961) transferred it to the Genus Polygnathus; 17 - Typical forms of Si. sulcata occur in the sulcata Zone of Sandberg et al. (1978) and therefore within the Pr. kockeli Zone.

\begin{tabular}{|c|c|c|c|}
\hline Taxon & Biostratigraphic range from literature & $\begin{array}{l}\text { Biostratigraphic range according to the new } \\
\text { global zonation }\end{array}$ & Notes \\
\hline $\begin{array}{l}\text { Alternognathus beulensis Ziegler \& } \\
\text { Sandberg, } 1984\end{array}$ & $\begin{array}{l}\text { Uppermost marginifera - Lower postera (Ziegler \& } \\
\text { Sandberg 1984) }\end{array}$ & Sc. vel. velifer - Po. styriacus & \\
\hline $\begin{array}{l}\text { Alternognathus pseudostrigosus } \\
\text { (Dreesen \& Dusar, 1974) }\end{array}$ & $\begin{array}{l}\text { Upper rhomboidea (Ziegler \& Sandberg 1984) - } \\
\text { Upper trachytera (Perri \& Spalletta 1998a) }\end{array}$ & Pa. gr. gracilis - Ps. granulosus & \\
\hline $\begin{array}{l}\text { Alternognathus regularis continuus } \\
\text { Hartenfels, } 2011\end{array}$ & Lower trachytera - Lower postera (Hartenfels 2011) & Pa.r. trachytera - Po. styriacus & \\
\hline $\begin{array}{l}\text { Alternognathus regularis regularis } \\
\text { Ziegler \& Sandberg, } 1984\end{array}$ & $\begin{array}{l}\text { Uppermost marginifera (Ziegler \& Sandberg 1984) - } \\
\text { Upper postera (Perri \& Spalletta 1998a) }\end{array}$ & Sc. vel. velifer-Pa. gr. manca & \\
\hline $\begin{array}{l}\text { Ancyrognathus bifurcatus (Ulrich \& } \\
\text { Bassler, 1926) }\end{array}$ & $\begin{array}{l}\text { Upper crepida (Over 2007) - Lower marginifera } \\
\text { (Wang et al. 2016) }\end{array}$ & Pa. glabra prima - Pa. marg. uthaensis & \\
\hline Ancyrognathus cryptus Ziegler, 1962a & $\begin{array}{l}\text { Lower triangularis - Uppermost crepida (Schülke } \\
\text { 1996) }\end{array}$ & Pa. triangularis - Pa. gl. pectinata & \\
\hline $\begin{array}{l}\text { Ancyrognathus sinelaminus (Branson \& } \\
\text { Mehl, 1934a) }\end{array}$ & $\begin{array}{l}\text { Middle triangularis - Uppermost crepida (Ziegler \& } \\
\text { Sandberg 1990) }\end{array}$ & Pa. del. platys - Pa. gl. pectinata & \\
\hline Ancyrolepis cruciformis Ziegler, 1959 & Middle crepida (Schülke 1996) & Pa. termini & \\
\hline $\begin{array}{l}\text { Antognathus mowitzaensis (Sandberg \& } \\
\text { Ziegler, 1979) }\end{array}$ & $\begin{array}{l}\text { ?Upper trachytera (Bultynck 2003) - Lower expansa } \\
\text { (Gatovsky 2008) }\end{array}$ & ?Ps. granulosus - Pa. gr. expansa & \\
\hline $\begin{array}{l}\text { Antognathus volnovachensis Lipnjagov } \\
\text { (in Kozitskaya et al.), } 1978\end{array}$ & Lower expansa - Middle expansa (Gatovsky 2008) & Pa. gr. expansa - Bi. costatus & \\
\hline $\begin{array}{l}\text { Antognathus vjatsheslavi Gatovsky, } \\
2008\end{array}$ & $\begin{array}{l}\text { Lower rhomboidea - Upper rhomboidea (Gatovsky } \\
\text { 2008) }\end{array}$ & Pa. rhomboidea - Pa. gr. gracilis & \\
\hline Barskovella katerinae Gatovsky, 2009 & $\begin{array}{l}\text { Lower marginifera - Uppermost marginifera } \\
\text { (Gatovsky 2009) }\end{array}$ & Pa. marg. marginifera -Sc. vel. velifer & \\
\hline $\begin{array}{l}\text { Bispathodus aculeatus aculeatus } \\
\text { (Branson \& Mehl, 1934a) }\end{array}$ & $\begin{array}{l}\text { Middle expansa (Ziegler \& Sandberg 1984) - texanus } \\
\text { (Lane } \text { et al. } 1980 \text { ) }\end{array}$ & Bi. ac. aculeatus - Visean & \\
\hline $\begin{array}{l}\text { Bispathodus aculeatus anteposicornis } \\
\text { (Scott, 1961) }\end{array}$ & Middle expansa - sandbergi (Ziegler et al. 1974) & Bi. ac. aculeatus - Tournaisian & \\
\hline $\begin{array}{l}\text { Bispathodus bispathodus Ziegler et al., } \\
1974\end{array}$ & $\begin{array}{l}\text { Upper postera - Middle praesulcata (Kaiser et al. } \\
\text { 2009) }\end{array}$ & Pa. gr. manca-Bi. ultimus & \\
\hline
\end{tabular}


Table 1 - continued

\begin{tabular}{|c|c|c|c|}
\hline Taxon & Biostratigraphic range from literature & $\begin{array}{l}\text { Biostratigraphic range according to the new } \\
\text { global zonation }\end{array}$ & Notes \\
\hline $\begin{array}{l}\text { Bispathodus costatus } \\
\text { (Branson, 1934) M1 }\end{array}$ & $\begin{array}{l}\text { Middle expansa-Middle praesulcata (Ziegler \& } \\
\text { Sandberg 1984) }\end{array}$ & Bi. costatus - Bi. ultimus & \\
\hline $\begin{array}{l}\text { Bispathodus costatus } \\
\text { (Branson, 1934) M2 }\end{array}$ & $\begin{array}{l}\text { Middle expansa-Middle praesulcata (Ziegler \& } \\
\text { Sandberg 1984) }\end{array}$ & Bi. costatus - Bi. ultimus & \\
\hline $\begin{array}{l}\text { Bispathodus jugosus (Branson \& Mehl, } \\
\text { 1934a) }\end{array}$ & $\begin{array}{l}\text { Lower expansa (Ziegler \& Sandberg 1984) - Lower } \\
\text { praesulcata (Corradini 2003) }\end{array}$ & Pa. gr. expansa - Bi. ultimus & \\
\hline $\begin{array}{l}\text { Bispathodus spinulicostatus (Branson, } \\
\text { 1934) }\end{array}$ & $\begin{array}{l}\text { Middle expansa (Ziegler et al. 1974) - Lower } \\
\text { crenulata (Sandberg et al. 1978) }\end{array}$ & Bi. ac. aculeatus - Tournaisian & \\
\hline $\begin{array}{l}\text { Bispathodus stabilis bituberculatus } \\
\text { (Dzik, 2006) [M3] }\end{array}$ & $\begin{array}{l}\text { Upper postera (Ziegler \& Sandberg 1990) - Middle } \\
\text { expansa (Hartenfels 2011) }\end{array}$ & Pa. gr. manca-Bi. ac. aculeatus & \\
\hline $\begin{array}{l}\text { Bispathodus stabilis stabilis (Branson \& } \\
\text { Meh1, 1934a) [M2] }\end{array}$ & $\begin{array}{l}\text { Upper trachytera (Girard et al. 2017) - Lower } \\
\text { crenulata (Sandberg et al. 1978) }\end{array}$ & Ps. granulosus - Tournaisian & \\
\hline $\begin{array}{l}\text { Bispathodus stabilis vulgaris (Dzik, } \\
\text { 2006) [M1] }\end{array}$ & $\begin{array}{l}\text { Upper rhomboidea (Girard et al. 2014) - Lower } \\
\text { crenulata (Sandberg et al. 1978) }\end{array}$ & Pa. gr. gracilis - Tournaisian & \\
\hline $\begin{array}{l}\text { Bispathodus stabilis zizensis Hartenfels, } \\
2011\end{array}$ & Upper trachytera - Lower expansa (Hartenfels 2011) & Ps. granulosus - Pa. gr. expansa & \\
\hline $\begin{array}{l}\text { Bispathodus ultimus } \\
\text { (Bischoff, 1957) M1 and M2 }\end{array}$ & $\begin{array}{l}\text { Upper expansa-Middle praesulcata (Ziegler \& } \\
\text { Sandberg 1984) }\end{array}$ & Bi. ultimus & \\
\hline $\begin{array}{l}\text { Bizignathus dissimilis (Helms \& } \\
\text { Wolska, 1967) }\end{array}$ & Lower expansa - Middle expansa (Corradini 1998) & Pa. gr. expansa - Bi. ac. aculeatus & \\
\hline $\begin{array}{l}\text { Bizignathus kayseri (Bischoff \& Ziegler, } \\
\text { 1956) }\end{array}$ & Lower expansa - Lower praesulcata (2009) & Pa. gr. expansa - Bi. ultimus & \\
\hline $\begin{array}{l}\text { Branmehla ampla (Branson \& Mehl, } \\
\text { 1934a) }\end{array}$ & $\begin{array}{l}\text { ?Upper rhomboidea (Dreesen \& Dusar 1974) - Middle } \\
\text { expansa (Hartenfels 2011) }\end{array}$ & ?Pa. gr. gracilis - Bi. ac. aculeatus & \\
\hline $\begin{array}{l}\text { Branmehla bohlenana bohlenana } \\
\text { (Helms, 1959) }\end{array}$ & $\begin{array}{l}\text { Upper marginifera (Spalletta \& Perri 1994) - Upper } \\
\text { expansa (Corradini 2003) }\end{array}$ & Pa. marg. utahensis - Bi. ultimus & \\
\hline $\begin{array}{l}\text { Branmehla bohlenana gediki } \\
\text { (Capkinoglu, 2000) }\end{array}$ & $\begin{array}{l}\text { Lower marginifera - Middle expansa (Capkinoglu } \\
\text { 2000) }\end{array}$ & Pa. marg. marginifera-Bi. ac. aculeatus & \\
\hline $\begin{array}{l}\text { Branmehla disparilis (Branson \& Mehl, } \\
\text { 1934a) }\end{array}$ & $\begin{array}{l}\text { Upper rhomboidea (Perri \& Spalletta unpubl.) - } \\
\text { Middle praesulcata (Spalletta et al. 1998) }\end{array}$ & Pa. gr. gracilis - Bi. ultimus & \\
\hline $\begin{array}{l}\text { Branmehla fissilis (Branson \& Mehl, } \\
\text { 1934a) }\end{array}$ & $\begin{array}{l}\text { Lower expansa - Upper expansa (Ziegler \& Sandberg } \\
\text { 1984) }\end{array}$ & Pa. gr. expansa - Bi. ultimus & \\
\hline $\begin{array}{l}\text { Branmehla inornata (Branson \& Mehl, } \\
\text { 1934a) }\end{array}$ & $\begin{array}{l}\text { Upper marginifera (Ziegler \& Sandberg 1984) - } \\
\text { ?hassi (Kaiser } \text { et al. 2009) }\end{array}$ & Pa. marg. uthaensis - Tournaisian & \\
\hline Branmehla suprema (Ziegler, 1962a) & $\begin{array}{l}\text { Upper expansa (Ziegler \& Sandberg 1984) - Upper } \\
\text { praesulcata (Kaiser et al. 2009) }\end{array}$ & Bi. ultimus - Pr. kockeli & \\
\hline Branmehla werneri (Ziegler, 1962a) & $\begin{array}{l}\text { Lower marginifera (Ziegler \& Sandberg 1984) - } \\
\text { Middle expansa (Hartenfels 2011) }\end{array}$ & Pa. marg. marginifera-Bi. ac. aculeatus & \\
\hline $\begin{array}{l}\text { Clydagnathus ormistoni Beinert et al., } \\
1971\end{array}$ & $\begin{array}{l}\text { Upper postera (Ziegler \& Sandberg 1984) - Middle } \\
\text { expansa (Hartenfels 2011) }\end{array}$ & Pa. gr. manca-Bi. ac. aculeatus & \\
\hline $\begin{array}{l}\text { Clydagnathus plumulus (Rhodes et al., } \\
\text { 1969) }\end{array}$ & $\begin{array}{l}\text { Middle expansa (Hartenfels 2011) - Lower duplicata } \\
\text { (Kaiser 2005) }\end{array}$ & Bi. ac. aculeatus - Tournaisian & \\
\hline $\begin{array}{l}\text { Dasbergina schaeferi Luppold (in Korn } \\
\text { \& Luppold), } 1987\end{array}$ & $\begin{array}{l}\text { ?Lower postera }(\text { Korn \& Luppold 1987) - Upper } \\
\text { expansa }(\text { Savage } 2013)\end{array}$ & ?Po. styriacus - Bi. ultimus & \\
\hline Dasbergina ziegleri Schäfer, 1976 & Lower expansa - Middle expansa (Hartenfels 2011) & Pa. gr. expansa-Bi. ac. aculeatus & \\
\hline $\begin{array}{l}\text { Icriodus alternatus alternatus Branson \& } \\
\text { Mehl, } 1934 \mathrm{a}\end{array}$ & $\begin{array}{l}\text { Upper rhenana - Uppermost crepida } \\
\text { (Bultynck 2003) }\end{array}$ & Frasnian - Pa. gl. pectinata & \\
\hline $\begin{array}{l}\text { Icriodus alternatus helmsi Sandberg \& } \\
\text { Dreesen, } 1984\end{array}$ & Upper rhenana - Middle crepida (Ji \& Ziegler 1993) & Frasnian - Pa. termini & \\
\hline $\begin{array}{l}\text { Icriodus alternatus mawsonae Yazdi, } \\
1999\end{array}$ & FZ 13c - Upper crepida (Perri \& Spalletta unpubl.) & Frasnian - Pa. gl. prima & \\
\hline Icriodus cornutus Sannemann, 1955b & $\begin{array}{l}\text { Middle triangularis (Sandberg \& Dreesen 1984) - } \\
\text { ?Upper trachytera (Bultynck 2003) }\end{array}$ & Pa. del. platys - Ps. granulosus & \\
\hline
\end{tabular}


Table 1 - continued

\begin{tabular}{|c|c|c|c|}
\hline Taxon & Biostratigraphic range from literature & $\begin{array}{l}\text { Biostratigraphic range according to the new } \\
\text { global zonation }\end{array}$ & Notes \\
\hline Icriodus costatus (Thomas, 1949) & $\begin{array}{l}\text { Uppermost marginifera - Lower expansa (Bultynck } \\
\text { 2003) }\end{array}$ & Sc. vel. velifer-Pa. gr. expansa & \\
\hline Icriodus chojnicensis Matyja, 1972 & $\begin{array}{l}\text { Upper rhomboidea - Uppermost marginifera } \\
\text { (Bultynck 2003) }\end{array}$ & Pa. rhomboidea - Sc. vel. velifer & \\
\hline Icriodus darbyensis Klapper, 1958 & Lower expansa - Upper expansa (Bultynck 2003) & Pa. gr. expansa-Bi. ultimus & \\
\hline $\begin{array}{l}\text { Icriodus deformatus asymmetricus Ji \& } \\
\text { Ziegler, } 1993\end{array}$ & $\begin{array}{l}\text { FZ 13c (Perri \& Spalletta unpubl.) - Upper } \\
\text { triangularis (Ji \& Ziegler 1993) }\end{array}$ & Frasnian $-P a$. min. minuta & \\
\hline $\begin{array}{l}\text { Icriodus deformatus deformatus Han, } \\
1987\end{array}$ & $\begin{array}{l}\text { FZ 13b (Perri \& Spalletta unpubl.) - Upper } \\
\text { triangularis (Ji \& Ziegler 1993) }\end{array}$ & Frasnian - Pa. min. minuta & \\
\hline $\begin{array}{l}\text { Icriodus iowaensis ancylus Sandberg \& } \\
\text { Dreesen, } 1984\end{array}$ & $\begin{array}{l}\text { Middle triangularis - Middle crepida } \\
\text { (Bultynck 2003) }\end{array}$ & Pa. del. platys $-P a$. termini & \\
\hline Icriodus iowaensis iowaensis & Lower rhenana (Bahrami et al. 2013) - Lower & Frasnian - Pa. rhomboidea & \\
\hline
\end{tabular}

Youngquist \& Peterson, 1947 rhomboidea (Bultynck 2003)

Icriodus olivierii Corradini, 1998

Uppermost crepida - Lower rhomboidea (Corradini 2003)

Icriodus raymondi Sandberg \& Ziegler, Uppermost marginifera-Middle expansa (Bultynck, Sc. vel. velifer-Bi. costatus 1979 2003)

Mehlina gradata (Branson \& Mehl, 1934a)

Late falsiovalis (Ziegler \& Sandberg 1990) - Lower marginifera (Klapper \& Ziegler 1979)

Mehlina strigosa (Branson \& Mehl, 1934a)

Middle crepida (Perri \& Spalletta unpubl.) - bransoni (Kaiser et al. 2009)

Palmatolepis adamantea Metzger, 1994 Upper crepida-Uppermost crepida (Metzger 1994)

Palmatolepis arta Klapper et al., 2004

Upper crepida (Klapper et al. 2004) - Uppermost crepida (Over 2007)

Palmatolepis circularis Szulczewski, 1971

Middle crepida - Upper crepida (Ji \& Ziegler 1993)

Palmatolepis clarki Ziegler, 1962a

Middle triangularis (Ziegler \& Sandberg 1990) Lower crepida (Perri \& Spalletta unpubl.)

Palmatolepis crepida Sannemann, 1955b Lower crepida - Lower rhomboidea (Ji \& Ziegler, 1993)

Palmatolepis delicatula delicatula Branson \& Mehl, 1934

Lower triangularis (Ziegler \& Sandberg 1990) Lower crepida (Perri \& Spalletta unbubl.)

Palmatolepis delicatula platys Ziegler \& Middle triangularis (Ziegler \& Sandberg 1990) Sandberg, 1990 Lower crepida (Perri \& Spalletta unpubl.)

Palmatolepis glabra acuta Helms, 1963 Uppermost crepida-Upper marginifera (Ji \& Ziegler 1993)

Palmatolepis glabra distorta Branson \& Lower marginifera (Ji \& Ziegler 1993) - Upper Mehl, 1934a trachytera (Over et al. 2009)

Palmatolepis glabra glabra Ulrich \& Bassler, 1926

Lower rhomboidea - Lower marginifera (Ji \& Ziegler 1993)

Palmatolepis glabra lepta Ziegler \& Huddle, 1969

Palmatolepis glabra pectinata Ziegler, 1962b M1 Sandberg \& Ziegler, 1973

Palmatolepis glabra pectinata Ziegler, 1962b

Upper crepida - Upper trachytera (Ji \& Ziegler 1993) Pa. gl. prima-Ps. granulosus

Palmatolepis glabra prima Ziegler \& Huddle, 1969

Uppermost crepida - Upper rhomboidea (Ji \& Ziegler Pa. gl. pectinata-Pa. gr. gracilis 1993)

Uppermost crepida - Upper marginifera (Ji \& Ziegler Pa. gl. pectinata-Pa. marg. utahensis 1993)

Upper crepida - Upper marginifera (Ji \& Ziegler

Pa. gl. prima-Pa. marg. utahensis

Palmatolepis gracilis expansa Sandberg Lower expansa-Middle praesulcata (Ji \& Ziegler \& Ziegler, 1979 1993)

Palmatolepis gracilis

Upper expansa - Lower praesulcata (Ziegler \&

Pa. gr. expansa-Bi. ultimus

gonioclymeniae Müller, 1956 Sandberg 1984)

Palmatolepis gracilis gracilis Branson \& Upper rhomboidea (Klapper \& Ziegler 1979) Mehl, 1934a ?Upper praesulcata (Ji \& Ziegler, 1993)

Bi. ultimus

Pa. gr. gracilis - ?Pr. kockeli 
Table 1 - continued

\begin{tabular}{lll}
\hline Taxon & Biostratigraphic range from literature & $\begin{array}{l}\text { Biostratigraphic range according to the new } \\
\text { global zonation }\end{array}$ \\
\hline $\begin{array}{l}\text { Palmatolepis gracilis manca Helms, } \\
1963\end{array}$ & $\begin{array}{l}\text { Upper postera (Ziegler \& Sandberg 1984) - Middle } \\
\text { expansa (Hartenfels 2011) }\end{array}$ & Pa. gr. manca - Bi. ac. aculeatus \\
Palmatolepis gracilis sigmoidalis & Upper trachytera - ?Upper praesulcata (Ji \& Ziegler, & Ps. granulosus - ?Pr. kockeli
\end{tabular}

Ziegler, 1962a

Palmatolepis klapperi Sandberg \& Ziegler, 1973 1993)

Upper crepida (Metzger 1994) - Lower marginifera $\quad$ Pa. gl. prima-Pa. marg. marginifera (Ji \& Ziegler 1993)

Palmatolepis lobicornis Schülke, 1995 Upper triangularis (Schülke 1999) - Lower rhomboidea (Perri \& Spalletta unpubl.)

Palmatolepis marginifera marginifera Helms, 1959

Palmatolepis marginifera duplicata Sandberg \& Ziegler, 1973

Palmatolepis marginifera utahensis Ziegler \& Sandberg, 1984

Lower marginifera - Lower trachytera (Ziegler \& Sandberg 1984).

Lower marginifera - Upper marginifera (Ji \& Ziegler 1993)

Upper marginifera (Ji \& Ziegler 1993) - Uppermost marginifera (Perri \& Spalletta 1990)

Palmatolepis minuta loba Helms, 1963

Lower crepida - Lower rhomboidea (Ji \& Ziegler 1993)

Palmatolepis minuta minuta Branson \& Mehl, 1934a

Palmatolepis minuta schleizia Helms, 1963

Palmatolepis minuta subgracilis Bischoff, 1956

Palmatolepis minuta wolskae Szulczewski, 1971

Palmatolepis perlobata grossi Ziegler (in Kronberg et al.) 1960 993)

Upper rhomboidea - Upper postera (Ji \& Ziegler 1993)

Upper crepida - Lower rhomboidea (Klapper \& Ziegler 1979)

Middle crepida Zone - Lower rhomboidea (Corradini Pa. termini-Pa. rhomboidea 2003)

Palmatolepis perlobata helmsi Ziegler, $1962 \mathrm{a}$

Palmatolepis perlobata maxima Müller, ?Upper rhomboidea (Metzger 1994) - Middle expansa 1956

Palmatolepis perlobata perlobata Ulrich Upper triangularis - Uppermost crepida (Ziegler \& \& Bassler, 1926

Palmatolepis perlobata postera Ziegler Lower postera - Upper expansa (Ji \& Ziegler 1993) (in Kronberg et al.) 1960

Palmatolepis perlobata schindewolfi Müller, 1956

Palmatolepis perlobata sigmoidea Ziegler, 1962a

Palmatolepis poolei Sandberg \& Ziegler, Lower rhomboidea (Ji \& Ziegler 1993) 1973

Palmatolepis protorhomboidea Sandberg \& Ziegler, 1973

Palmatolepis quadrantinodosa inflexa Müller, 1956

Palmatolepis quadrantinodosa inflexoidea Ziegler, 1962a

Palmatolepis quadrantinodosa quadrantinodosa Branson \& Mehl, $1934 \mathrm{a}$

Palmatolepis quadrantinodosalobata Sannemann, 1955a M1 Sandberg \& Ziegler, 1973

Palmatolepis quadrantinodosalobata Sannemann, 1955a M2 Ji \& Ziegler, 1993
Upper marginifera Zone - Upper trachytera (Ziegler \& Sandberg 1984)

Lower rhomboidea (Hartenfels 2011) - Middle expansa (Ziegler \& Sandberg 1984) (Hartenfels 2011) Sandberg 1984)

Upper crepida - Upper expansa (Ji \& Ziegler 1993)

Lower marginifera - Upper postera

(Ji \& Ziegler 1993)

Lower triangularis - Lower rhomboidea (Ji \& Ziegler Pa. subperlobata-Pa. rhomboidea 1993)

Upper rhomboidea (Ji \& Ziegler 1993) - Upper marginifera (Perri \& Spalletta 1998c)

Lower marginifera (Ji \& Ziegler 1993) - Upper marginifera (Savage 2013)

Lower marginifera (Ji \& Ziegler 1993)

Pa. m. utahensis - Ps. granulosus

Pa. rhomboidea - Bi. ac. aculeatus

?Pa. gr-gracilis - Bi. ac. aculeatus

Pa. min. minuta - Pa. gl. pectinata

Po. styriacus - ?Bi. ultimus

Pa. gl. prima - ?Bi. ultimus

Pa. marg. marginifera - Pa. gr. manca

Pa. rhomboidea

Pa. gr. gracilis - Pa. marg. utahensis

Pa. marg. marginifera-Pa. marg. utahensis

Pa. marg. marginifera

Uppermost crepida - Lower rhomboidea (Sandberg \& Pa. gl. pectinata - Pa. rhomboidea Ziegler 1973)

Lower crepida - Lower rhomboidea (Ji \& Ziegler $\quad$ Pa. crepida - Pa. rhomboidea 1993) 
Table 1 - continued

\begin{tabular}{|c|c|c|c|}
\hline Taxon & Biostratigraphic range from literature & $\begin{array}{l}\text { Biostratigraphic range according to the new } \\
\text { global zonation }\end{array}$ & Notes \\
\hline Palmatolepis regularis Cooper, 1931 & $\begin{array}{l}\text { Upper triangularis - Lower rhomboidea (Ji \& Ziegler } \\
\text { 1993) }\end{array}$ & Pa. min. minuta - Pa. rhomboidea & \\
\hline $\begin{array}{l}\text { Palmatolepis rhomboidea Sannemann, } \\
\text { 1955a }\end{array}$ & $\begin{array}{l}\text { Lower rhomboidea (Klapper \& Ziegler 1979) - Upper } \\
\text { marginifera (Corradini 2003) }\end{array}$ & Pa. rhomboidea - Pa. marg. utahensis & \\
\hline Palmatolepis robusta Schülke, 1995 & Upper triangularis - Lower crepida (Schülke 1999) & Pa. min. minuta - Pa. crepida & \\
\hline Palmatolepis rugosa ampla Müller, 1956 & $\begin{array}{l}\text { Lower postera (Perri \& Spalletta 1991) - Upper } \\
\text { expansa (Ji \& Ziegler 1993) }\end{array}$ & Po. styriacus - ?Bi. ultimus & 10 \\
\hline $\begin{array}{l}\text { Palmatolepis rugosa cf. ampla Müller, } \\
1956, \text { sensu Ziegler (in Kronberg et al.) } \\
1960\end{array}$ & $\begin{array}{l}\text { Upper marginifera (Ji \& Ziegler 1993) - Lower } \\
\text { postera (Mossoni 2014) }\end{array}$ & Pa. marg. utahensis - Po. styriacus & \\
\hline $\begin{array}{l}\text { Palmatolepis rugosa rugosa Branson \& } \\
\text { Mehl, } 1934\end{array}$ & $\begin{array}{l}\text { Upper postera (Hartenfels 2011) - Upper expansa (Ji } \\
\text { \& Ziegler 1993) }\end{array}$ & Pa. gr. manca - ?Bi. ultimus & 11 \\
\hline $\begin{array}{l}\text { Palmatolepis rugosa trachytera Ziegler } \\
\text { (in Kronberg et al.) } 1960\end{array}$ & $\begin{array}{l}\text { Lower trachytera - Upper trachytera (Ji \& Ziegler } \\
\text { 1993) }\end{array}$ & Pa. rug. trachytera - Ps. granulosus & 12 \\
\hline $\begin{array}{l}\text { Palmatolepis sandbergi Ji \& Ziegler, } \\
1993\end{array}$ & $\begin{array}{l}\text { Upper triangularis - Lower crepida (Ji \& Ziegler } \\
\text { 1993) }\end{array}$ & Pa. min. minuta - Pa. crepida & \\
\hline Palmatolepis spathula Schülke, 1995 & Upper triangularis - Lower crepida (Schülke 1995) & Pa. min. minuta - Pa. crepida & \\
\hline $\begin{array}{l}\text { Palmatolepis stoppeli Sandberg \& } \\
\text { Ziegler, } 1973\end{array}$ & $\begin{array}{l}\text { Upper rhomboidea - Lower marginifera (Ji \& Ziegler } \\
\text { 1993) }\end{array}$ & Pa. gr. gracilis - Pa. marg. marginifera & \\
\hline $\begin{array}{l}\text { Palmatolepis subperlobata Branson \& } \\
\text { Mehl, } 1934\end{array}$ & $\begin{array}{l}\text { Lower triangularis (Klapper 2007b) - Lower } \\
\text { marginifera (Ji \& Ziegler 1993) }\end{array}$ & Pa. subperlobata - Pa. marg. marginifera & \\
\hline $\begin{array}{l}\text { Palmatolepis tenuipunctata Sannemann, } \\
1955 \mathrm{~b}\end{array}$ & $\begin{array}{l}\text { Upper triangularis - Uppermost crepida (Ji \& Ziegler } \\
\text { 1993) }\end{array}$ & Pa. min. minuta - Pa. gl. pectinata & \\
\hline Palmatolepis termini Sannemann, 1955b & Middle crepida - Upper crepida (Ji \& Ziegler 1993) & Pa. termini-Pa. gl. prima & \\
\hline $\begin{array}{l}\text { Palmatolepis triangularis Sannemann, } \\
\text { 1955a }\end{array}$ & $\begin{array}{l}\text { Lower triangularis - Lower crepida (Ziegler \& } \\
\text { Sandberg 1990) }\end{array}$ & Pa. triangularis - Pa. crepida & \\
\hline Palmatolepis ultima Ziegler, 1958 & FZ 13c - Middle triangularis (Klapper 2007b) & Frasnian - Pa. del. platys & \\
\hline $\begin{array}{l}\text { Palmatolepis weddigei Ji \& Ziegler, } \\
1993\end{array}$ & $\begin{array}{l}\text { Upper triangularis - Middle crepida (Ji \& Ziegler } \\
\text { 1993) }\end{array}$ & Pa. min. minuta - Pa. termini & \\
\hline Palmatolepis werneri Ji \& Ziegler, 1993 & $\begin{array}{l}\text { Upper triangularis - Middle crepida (Ji \& Ziegler } \\
\text { 1993) }\end{array}$ & Pa. min. minuta - Pa. termini & \\
\hline $\begin{array}{l}\text { Palmatolepis wolskajae Ovnatanova, } \\
1969\end{array}$ & Lower crepida - Upper crepida (Schülke 1999) & Pa. crepida - Pa. gl. prima & \\
\hline $\begin{array}{l}\text { Pelekysgnathus brevis Sandberg \& } \\
\text { Dreesen, } 1984\end{array}$ & kockelianus - Uppermost crepida (Bultynck 2003) & Eifelian - Pa. gl. pectinata & \\
\hline Pelekysgnathus inclinatus Thomas, 1949 & $\begin{array}{l}\text { Middle triangularis (Huang \& Gong 2016) - Upper } \\
\text { praesulcata (Sandberg \& Dreesen 1984) }\end{array}$ & Pa. del. platys - Pr. kockeli & \\
\hline $\begin{array}{l}\text { Pelekysgnathus planus Sannemann, } \\
\text { 1955b }\end{array}$ & Lower rhenana - Upper crepida (Corradini 2003) & Frasnian - Pa. gl. prima & \\
\hline $\begin{array}{l}\text { Pelekysgnathus serradentatus } \\
\text { Capkinoglu, } 1991\end{array}$ & $\begin{array}{l}\text { Middle triangularis (Capkinoglu \& Gedik 2000) - } \\
\text { Uppermost crepida (Bahrami et al. 2013) }\end{array}$ & Pa. del. platys - Pa. gl. pectinata & \\
\hline $\begin{array}{l}\text { Polygnathus angustidiscus Branson \& } \\
\text { Mehl, } 1934 \mathrm{a}\end{array}$ & $\begin{array}{l}\text { Upper subterminus Fauna (Witzke et al. 1989) - } \\
\text { Middle crepida (Perri \& Spalletta unpubl.) }\end{array}$ & Givetian - Pa. termini & \\
\hline $\begin{array}{l}\text { Polygnathus brevilaminus Branson \& } \\
\text { Mehl, 1934a }\end{array}$ & $\begin{array}{l}\text { linguiformis (Schülke 1995) - Upper trachytera } \\
\text { (Hartenfels 2011) }\end{array}$ & Frasnian - Ps. granulosus & 13 \\
\hline Polygnathus buzmakovi Kuz'min, 1990 & $\begin{array}{l}\text { Upper triangularis (Perri \& Spalletta unpubl.) - } \\
\text { Lower marginifera (Molloy et al. 1997) }\end{array}$ & Pa. min. minuta - Pa. marg. marginifera & \\
\hline $\begin{array}{l}\text { Polygnathus communis collinsoni Druce, } \\
1969\end{array}$ & $\begin{array}{l}\text { Lower postera (Druce 1976) - Middle praesulcata } \\
\text { (Ji \& Ziegler 1993) }\end{array}$ & Po. styriacus - Bi. ultimus & \\
\hline $\begin{array}{l}\text { Polygnathus communis communis } \\
\text { Branson \& Mehl, 1934b }\end{array}$ & $\begin{array}{l}\text { Lower crepida (Schülke 1998) - texanus (Lane et al. } \\
\text { 1980) }\end{array}$ & Pa. crepida-Visean & \\
\hline $\begin{array}{l}\text { Polygnathus communis dentatus Druce, } \\
1969\end{array}$ & $\begin{array}{l}\text { Uppermost marginifera - Lower crenulata (Ji \& } \\
\text { Ziegler 1993) }\end{array}$ & Sc. v. velifer - Tournaisian & \\
\hline
\end{tabular}


Table 1 - continued

\begin{tabular}{|c|c|c|}
\hline Taxon & Biostratigraphic range from literature & $\begin{array}{l}\text { Biostratigraphic range according to the new Notes } \\
\text { global zonation }\end{array}$ \\
\hline $\begin{array}{l}\text { Polygnathus communis renatae } \\
\text { Corradini \& Spalletta } \\
\text { (in Corradini } \text { et al.), } 2003\end{array}$ & $\begin{array}{l}\text { Lower praesulcata - Lower duplicata (Mossoni et al. } \\
\text { 2015) }\end{array}$ & Bi. ultimus - Tournaisian \\
\hline $\begin{array}{l}\text { Polygnathus delicatulus Ulrich \& } \\
\text { Bassler, } 1926\end{array}$ & $\begin{array}{l}\text { Upper styriacus - Lower costatus (Klapper in Ziegler } \\
\text { 1975) }\end{array}$ & Pa. gr. manca-Bi. costatus \\
\hline Polygathus diversus Helms, 1959 & $\begin{array}{l}\text { Lower rhomboidea (Corradini 2003) - styriacus } \\
\text { (Glenister \& Klapper 1966) }\end{array}$ & Pa. rhomboidea - Po. styriacus \\
\hline $\begin{array}{l}\text { Polygnathus doulingshanensis Ji \& } \\
\text { Ziegler, } 1993\end{array}$ & $\begin{array}{l}\text { Uppermost marginifera - Upper trachytera (Ji \& } \\
\text { Ziegler 1993) }\end{array}$ & Sc. vel. velifer-Ps. granulosus \\
\hline Polygnathus eoglaber Ji \& Ziegler, 1993 & $\begin{array}{l}\text { Upper triangularis - Upper rhomboidea (Ji \& Ziegler } \\
\text { 1993) }\end{array}$ & Pa. min. minuta - Pa. gr. gracilis \\
\hline $\begin{array}{l}\text { Polygnathus experplexus Sandberg \& } \\
\text { Ziegler, } 1979\end{array}$ & $\begin{array}{l}\text { Upper postera (Hartenfels 2011) - Middle expansa } \\
\text { (Ji \& Ziegler 1993) }\end{array}$ & Pa. gr. manca-Bi. costatus \\
\hline Polygnathus extralobatus Schäfer, 1976 & Lower expansa - Upper expansa (Ji \& Ziegler 1993) & Pa. gr. expansa - Bi. ultimus \\
\hline $\begin{array}{l}\text { Polygnathus glaber bilobatus Ziegler, } \\
\text { 1962a }\end{array}$ & $\begin{array}{l}\text { Lower marginifera - Lower trachytera (Ji \& Ziegler } \\
\text { 1993) }\end{array}$ & Pa. marg. marginifera - Pa. rug. trachytera \\
\hline $\begin{array}{l}\text { Polygnathus glaber glaber Ulrich \& } \\
\text { Bassler, } 1926\end{array}$ & $\begin{array}{l}\text { Middle crepida (Girard et al. 2014) - Lower } \\
\text { trachytera (Ji \& Ziegler 1993) }\end{array}$ & Pa. termini - Pa. rug. trachytera \\
\hline $\begin{array}{l}\text { Polygnathus glaber medius Helms \& } \\
\text { Wolska, } 1967\end{array}$ & $\begin{array}{l}\text { Lower marginifera - Upper marginifera (Ji \& Ziegler } \\
\text { 1993) }\end{array}$ & Pa. marg. marginifera - Pa. marg. utahensis \\
\hline $\begin{array}{l}\text { Polygnathus granulosus Branson \& } \\
\text { Mehl, 1934a }\end{array}$ & $\begin{array}{l}\text { Upper marginifera (Corradini 2003) - Upper expansa } \\
\text { (Ji \& Ziegler 1993) }\end{array}$ & Pa. marg. utahensis - Bi. ultimus \\
\hline $\begin{array}{l}\text { Polygnathus guttiformis Khalymbadzha } \\
\text { et al., } 1992\end{array}$ & $\begin{array}{l}\text { Middle triangularis - Lower? marginifera (Schülke } \\
\text { 1995) }\end{array}$ & $\begin{array}{l}\text { Pa. delicatula platys - ?Pa. marg. } \\
\text { marginifera }\end{array}$ \\
\hline Polygnathus hassi Helms, 1961 & $\begin{array}{l}\text { Lower expansa - Middle expansa (Ziegler \& } \\
\text { Sandberg 1984) }\end{array}$ & Pa. gr. expansa - Bi. costatus \\
\hline $\begin{array}{l}\text { Polygnathus homoirregularis Helms, } \\
1961\end{array}$ & $\begin{array}{l}\text { Upper trachytera - Middle expansa (Ji \& Ziegler } \\
\text { 1993) }\end{array}$ & Ps. granulosus - Bi. costatus \\
\hline $\begin{array}{l}\text { Polygnathus inornatus Branson \& Mehl, } \\
\text { 1934b }\end{array}$ & Middle?expansa - anchoralis (Bahrami et al. 2011) & ?Bi. costatus - Tournaisian \\
\hline $\begin{array}{l}\text { Polygnathus lagowiensis Helms \& } \\
\text { Wolska, } 1967\end{array}$ & $\begin{array}{l}\text { Upper marginifera - Uppermost marginifera } \\
\text { (Klapper in Ziegler 1975) }\end{array}$ & Pa. marg. utahensis - Sc. vel. velifer \\
\hline $\begin{array}{l}\text { Polygnathus lauriformis Dreesen \& } \\
\text { Dusar, } 1974\end{array}$ & $\begin{array}{l}\text { Middle crepida (Dreesen \& Dusar 1974) - Uppermost } \\
\text { marginifera (Perri \& Spalletta 1990) }\end{array}$ & Pa. termini-Sc. vel. velifer \\
\hline $\begin{array}{l}\text { Polygnathus longiposticus Branson \& } \\
\text { Mehl, 1934b }\end{array}$ & $\begin{array}{l}\text { ?Lower praesulcata (Wang \& Yin 1988)- } \\
\text { isosticha-Upper crenulata (Sandberg et al. 1978) }\end{array}$ & ?Bi. ultimus - Tournaisian \\
\hline $\begin{array}{l}\text { Polygnathus margaretae Kononova \& } \\
\text { Weyer, } 2013\end{array}$ & Lower praesulcata (Kononova \& Weyer 2013) & Bi. ultimus \\
\hline Polygnathus margaritatus Schäfer, 1976 & Upper trachytera - Middle expansa (Hartenfels 2011) & Ps. granulosus - Bi. costatus \\
\hline Polygnathus marginvolutus Gedik, 1969 & $\begin{array}{l}\text { Upper marginifera (Perri \& Spalletta 1998b) - Upper } \\
\text { expansa (Ziegler \& Sandberg 1984) }\end{array}$ & Pa. marg. utahensis - Bi. ultimus \\
\hline $\begin{array}{l}\text { Polygnathus nodocostatus nodocostus } \\
\text { Branson \& Mehl, 1934a }\end{array}$ & Lower crepida - Lower expansa (Ji \& Ziegler 1993) & Pa. crepida-Pa. gr. expansa \\
\hline $\begin{array}{l}\text { Polygnathus nodocostatus ovatus, } \\
\text { Helms, } 1961\end{array}$ & Upper crepida - Lower postera (Hartenfels 2011) & Pa. glabra prima - Po. styriacus \\
\hline Polygnathus nodoundatus Helms, 1961 & $\begin{array}{l}\text { Upper marginifera - Lower trachytera (Perri \& } \\
\text { Spalletta 1990) }\end{array}$ & Pa. marg. utahensis - Pa. rug. trachytera \\
\hline $\begin{array}{l}\text { Polygnathus obliquicostatus Ziegler, } \\
\text { 1962a }\end{array}$ & $\begin{array}{l}\text { Upper trachytera (Hartenfels 2011) - Lower } \\
\text { praesulcata (Corradini et al. 2003) }\end{array}$ & Ps. granulosus - Bi. ultimus \\
\hline $\begin{array}{l}\text { Polygnathus padovanii Perri \& Spalletta, } \\
1990\end{array}$ & $\begin{array}{l}\text { Uppermost?crepida - Upper trachytera (Hartenfels } \\
\text { 2011) }\end{array}$ & ?Pa. gl. pectinata - Ps. granulosus \\
\hline $\begin{array}{l}\text { Polygnathus pennatuloideus Holmes, } \\
1928\end{array}$ & $\begin{array}{l}\text { Lower marginifera (Perri \& Spalletta unpubl.) - } \\
\text { Lower expansa (Ji \& Ziegler 1993) }\end{array}$ & Pa. marg. marginifera - Pa. gr. expansa \\
\hline
\end{tabular}


Table 1 - continued

\begin{tabular}{|c|c|c|c|}
\hline Taxon & Biostratigraphic range from literature & $\begin{array}{l}\text { Biostratigraphic range according to the new } \\
\text { global zonation }\end{array}$ & Notes \\
\hline Polygnathus perplexus Thomas, 1949 & $\begin{array}{l}\text { Upper marginifera (Dreesen \& Dusar 1974) - Upper } \\
\text { expansa (Ziegler \& Sandberg 1984) }\end{array}$ & Pa. marg. utahensis - Bi. ultimus & \\
\hline $\begin{array}{l}\text { Polygnathus planirostratus Dreesen \& } \\
\text { Dusar, } 1974\end{array}$ & $\begin{array}{l}\text { Lower rhomboidea - Lower trachytera (Dreesen \& } \\
\text { Dusar 1974) }\end{array}$ & Pa. rhomboidea - Pa. rug. trachytera & \\
\hline Polygnathus pomeranicus Matyja, 1993 & $\begin{array}{l}\text { Upper/Uppermost crepida (Wang et al. 2016) - } \\
\text { Uppermost marginifera (Matyja 1993) }\end{array}$ & $\begin{array}{l}\text { Pa. gl. prima/Pa. gl. pectinata -Sc. vel. } \\
\text { velifer }\end{array}$ & \\
\hline Polygnathus praecursor Mattyja, 1993 & $\begin{array}{l}\text { Beginning of Famennian - Lower crepida (Dzik } \\
\text { 2006) }\end{array}$ & Pa. subperlobata - Pa. crepida & \\
\hline Polygnathus praehassi Schäfer, 1976 & $\begin{array}{l}\text { Lower postera (Mossoni 2014) - Upper expansa } \\
\text { (Ziegler \& Sandberg 1984) }\end{array}$ & Po. styriacus - Bi. ultimus & \\
\hline $\begin{array}{l}\text { Polygnathus procerus Sannemann, } \\
1955 \mathrm{~b}\end{array}$ & $\begin{array}{l}\text { Upper triangularis (Perri \& Spalletta unpubl.) - } \\
\text { Uppermost crepida (Corradini 2003) }\end{array}$ & Pa. min. minuta - Pa. gl. pectinata & 14 \\
\hline $\begin{array}{l}\text { Polygnathus protostyriacus Tragelehn \& } \\
\text { Hartenfels, } 2011\end{array}$ & Upper trachytera - Lower expansa (Hartenfels 2011) & Ps. granulosus - Pa. gr. expansa & \\
\hline Polygnathus purus purus Voges, 1959 & $\begin{array}{l}\text { Upper expansa - Lower crenulata (Corradini et al. } \\
\text { 2003) }\end{array}$ & Bi. ultimus - Tournaisian & \\
\hline $\begin{array}{l}\text { Polygnathus purus subplanus Voges, } \\
1959\end{array}$ & sulcata - Upper duplicata (Sandberg et al. 1978) & Pr. kockeli-Tournaisian & \\
\hline Polygnathus ratebi Yazdi, 1999 & $\begin{array}{l}\text { Upper triangularis - Uppermost crepida } \\
\text { (Bahrami } \text { et al. 2013) }\end{array}$ & Pa. min. minuta - Pa. gl. pectinata & \\
\hline Polygnathus restrictus Vorontsova, 1993 & $\begin{array}{l}\text { Lower styriacus - Middle praesulcata (Vorontsova } \\
\text { 1993) }\end{array}$ & Po. styriacus - Bi. ultimus & \\
\hline Polygnathus rhabdotus Schäfer, 1976 & $\begin{array}{l}\text { Lower postera (Schäfer 1976) - Middle expansa } \\
\text { (Hartenfels 2011) }\end{array}$ & Po. styriacus - Bi. costatus & \\
\hline Polygnathus rhomboideus Helms, 1961 & $\begin{array}{l}\text { Uppermost crepida - Upper rhomboidea (Perri \& } \\
\text { Spalletta unpubl.) }\end{array}$ & Pa. gl. pectinata - Pa. gr. gracilis & \\
\hline $\begin{array}{l}\text { Polygnathus semicostatus Branson \& } \\
\text { Mehl, 1934a }\end{array}$ & Middle crepida - Upper expansa (Ji \& Ziegler 1993) & Pa. termini-Bi. ultimus & \\
\hline Polygnathus spicatus Branson, 1934 & $\begin{array}{l}\text { Middle expansa (Kalvoda \& Kukal 1987) - sulcata } \\
\text { (Sandberg et al. } 1974)\end{array}$ & Bi. costatus - Pr. kockeli & \\
\hline $\begin{array}{l}\text { Polygnathus spiculiferus Hartenfels, } \\
2011\end{array}$ & Lower expansa (Hartenfels 2011) & Pa. gr. expansa & \\
\hline $\begin{array}{l}\text { Polygnathus styriacus Ziegler (in Flügel } \\
\text { \& Ziegler), } 1957\end{array}$ & Lower postera - Lower expansa (Ji \& Ziegler 1993) & Po. styriacus - Pa. gr. expansa & \\
\hline $\begin{array}{l}\text { Polygnathus subirregularis Ziegler \& } \\
\text { Sandberg, } 1979\end{array}$ & $\begin{array}{l}\text { Lower trachytera - Lower expansa (Ziegler \& } \\
\text { Sandberg 1984) }\end{array}$ & Pa. rug. trachytera - Pa. gr. expansa & \\
\hline $\begin{array}{l}\text { Polygnathus subnormalis } \\
\text { Vorontsova \& Kuz'min, } 1984\end{array}$ & $\begin{array}{l}\text { Lower rhomboidea - Upper trachytera } \\
\text { (Kuz'min 1990) }\end{array}$ & Pa. rhomboidea - Ps. granulosus & \\
\hline Polygnathus symmetricus Branson, 1934 & $\begin{array}{l}\text { Upper expansa - Upper sandbergi (Perri \& Spalletta } \\
\text { 2001) }\end{array}$ & Bi. ultimus - Tournaisian & \\
\hline Polygnathus tenellus Ji \& Ziegler, 1993 & $\begin{array}{l}\text { Lower rhenana - Lower triangularis (Ji \& Ziegler } \\
\text { 1993) }\end{array}$ & Frasnian - Pa. triangularis & \\
\hline Polygnathus triphyllatus Helms, 1961 & $\begin{array}{l}\text { Upper rhomboidea - Lower marginifera (Klapper \& } \\
\text { Ziegler 1979) }\end{array}$ & Pa. gr. gracilis - Pa. marg. marginifera & 15 \\
\hline Polygnathus vogesi Ziegler, 1962a & $\begin{array}{l}\text { Lower expansa (Ji \& Ziegler 1993) - Upper duplicata } \\
\text { (Bardasheva } \text { et al. 2004) }\end{array}$ & Pa. gr. expansa-Tournaisian & \\
\hline $\begin{array}{l}\text { Polygnathus zikmundovae Zhuralev, } \\
1991\end{array}$ & Upper praesulcata - sulcata (Vorontsova 1993) & Bi. ultimus - Pr. kockeli & \\
\hline Polygnathus znepolensis Spassov, 1965 & $\begin{array}{l}\text { Lower expansa (Hartenfels 2011) - Lower } \\
\text { praesulcata (Ziegler \& Sandberg 1984) }\end{array}$ & Pa. gr. expansa - Bi. ultimus & \\
\hline $\begin{array}{l}\text { Polylophodonta concentrica (Ulrich \& } \\
\text { Bassler, 1926) }\end{array}$ & Lower trachytera - Lower postera (Hartenfels 2011) & Pa. rug. trachytera - Po. styriacus & \\
\hline $\begin{array}{l}\text { Polylophodonta confluens (Ulrich \& } \\
\text { Bassler, 1926) }\end{array}$ & $\begin{array}{l}\text { Lower rhomboidea - Uppermost marginifera (Over } \\
\text { et al. 2009) }\end{array}$ & Pa. rhomboidea -Sc. vel. velifer & \\
\hline
\end{tabular}


Table 1 - continued

\begin{tabular}{|c|c|c|c|}
\hline Taxon & Biostratigraphic range from literature & $\begin{array}{l}\text { Biostratigraphic range according to the new } \\
\text { global zonation }\end{array}$ & Notes \\
\hline $\begin{array}{l}\text { Polylophodonta gyratilineata Holmes, } \\
1928\end{array}$ & $\begin{array}{l}\text { Upper rhomboidea - Lower marginifera (Klapper \& } \\
\text { Ziegler 1979) }\end{array}$ & Pa. gr. gracilis - Pa. marg. marginifera & \\
\hline $\begin{array}{l}\text { Polylophodonta linguiformis Branson \& } \\
\text { Mehl, } 1934\end{array}$ & $\begin{array}{l}\text { Uppermost crepida (Ziegler \& Sandberg 1973) - } \\
\text { Upper marginifera (Perri \& Spalletta 1990) }\end{array}$ & Pa. gl. pectinata - Pa. marg. utahensis & \\
\hline Protognathodus collinsoni Ziegler, 1969 & $\begin{array}{l}\text { Lower praesulcata - Upper duplicata (Corradini } \\
\text { et al. 2011) }\end{array}$ & Bi. ultimus - Tournaisian & \\
\hline $\begin{array}{l}\text { Protognathodus meischneri Ziegler, } \\
1969\end{array}$ & $\begin{array}{l}\text { Upper expansa - Upper duplicata (Corradini et al. } \\
\text { 2011) }\end{array}$ & Bi. ultimus - Tournaisian & \\
\hline Protognathodus kockeli (Bischoff, 1957) & $\begin{array}{l}\text { Upper praesulcata - Lower crenulata (Corradini } \\
\text { et al. 2011) }\end{array}$ & Pr. kockeli-Tournaisian & \\
\hline $\begin{array}{l}\text { Protognathodus kuehni Ziegler \& } \\
\text { Leuteritz (in Koch et al.), } 1970\end{array}$ & sulcata - sandbergi (Corradini et al. 2011) & Pr. kockeli-Tournaisian & \\
\hline $\begin{array}{l}\text { Pseudopolygnathus brevipennatus } \\
\text { Ziegler, 1962a }\end{array}$ & $\begin{array}{l}\text { Upper postera (Hartenfels 2011) - Upper expansa } \\
\text { (Ziegler \& Sandberg 1984) }\end{array}$ & Pa. gr. manca-Bi. ultimus & \\
\hline $\begin{array}{l}\text { Pseudopolygnathus controversus } \\
\text { Sandberg \& Ziegler, } 1979\end{array}$ & $\begin{array}{l}\text { Upper postera - Middle expansa (Ziegler \& Sandberg } \\
\text { 1984) }\end{array}$ & Pa. gr. manca-Bi. costatus & \\
\hline $\begin{array}{l}\text { Pseudopolygnathus granulosus Ziegler, } \\
1962 \mathrm{a}\end{array}$ & Upper trachytera - Upper postera (Hartenfels 2011) & Ps. granulosus - Pa. gr. manca & \\
\hline $\begin{array}{l}\text { Pseudopolygnathus inordinatus } \\
\text { Tragelehn \& Hartenfels, } 2011\end{array}$ & Upper postera - Lower expansa (Hartenfels 2011) & Pa. gr. manca-Pa. gr. expansa & \\
\hline $\begin{array}{l}\text { Pseudopolygnathus marburgensis } \\
\text { marburgensis Bischoff \& Ziegler, } 1956\end{array}$ & $\begin{array}{l}\text { Lower expansa - Upper expansa (Ziegler \& Sandberg } \\
\text { 1984) }\end{array}$ & Pa. gr. expansa - Bi. ultimus & \\
\hline $\begin{array}{l}\text { Pseudopolygnathus marburgensis } \\
\text { trigonicus Ziegler, } 1962 \mathrm{a}\end{array}$ & $\begin{array}{l}\text { Upper expansa-Middle praesulcata (Ziegler \& } \\
\text { Sandberg 1984) }\end{array}$ & Bi. ultimus & \\
\hline $\begin{array}{l}\text { Pseudopolygnathus micropunctatus } \\
\text { Bischoff \& Ziegler, } 1956\end{array}$ & $\begin{array}{l}\text { Upper trachytera (Perri \& Spalletta 1991) - Upper } \\
\text { expansa (Corradini 2003) }\end{array}$ & Ps. granulosus - Bi. ultimus & \\
\hline $\begin{array}{l}\text { Pseudopolygnathus primus Branson \& } \\
\text { Mehl, } 1934\end{array}$ & $\begin{array}{l}\text { Lower expansa (Klapper in Ziegler 1981) - Lower } \\
\text { crenulata (Sandberg et al. 1974) }\end{array}$ & Pa. gr. expansa - Tournaisian & \\
\hline $\begin{array}{l}\text { Scaphignathus peterseni Sandberg \& } \\
\text { Ziegler, } 1979\end{array}$ & $\begin{array}{l}\text { Upper postera - Lower expansa (Ziegler \& Sandberg } \\
\text { 1984) }\end{array}$ & Pa. gr. manca-Pa. gr. expansa & \\
\hline $\begin{array}{l}\text { Scaphignathus velifer leptus Ziegler \& } \\
\text { Sandberg, } 1984\end{array}$ & $\begin{array}{l}\text { Uppermost marginifera - Upper postera (Ziegler \& } \\
\text { Sandberg 1984) }\end{array}$ & Sc. vel. velifer-Pa. gr. manca & \\
\hline $\begin{array}{l}\text { Scaphignathus velifer velifer Helms, } \\
1959\end{array}$ & $\begin{array}{l}\text { Uppermost marginifera - Upper trachytera (Ziegler \& } \\
\text { Sandberg 1984) }\end{array}$ & Sc. vel. velifer-Ps. granulosus & 16 \\
\hline Scaphignathus ziegleri Druce, 1969 & Lower expansa (Ziegler \& Sandberg 1984) & Pa. gr. expansa & \\
\hline $\begin{array}{l}\text { Siphonodella praesulcata Sandberg (in } \\
\text { Sandberg et al.), } 1972\end{array}$ & $\begin{array}{l}\text { Lower praesulcata - Lower duplicata } \\
\text { (Sandberg et al. 1978) }\end{array}$ & Bi. ultimus - Tournaisian & \\
\hline Siphonodella sulcata (Huddle, 1934) & $\begin{array}{l}\text { ?Upper praesulcata (Kaiser \& Corradini 2011) - } \\
\text { Lower crenulata (Sandberg et al. 1978) }\end{array}$ & Pr. kockeli-Tournaisian & 17 \\
\hline
\end{tabular}

